\title{
Lipid and gross energy content of North Atlantic right whale food, Calanus finmarchicus, in the Bay of Fundy
}

\author{
Josée Michaud $^{1,2, *}$, Christopher T. Taggart ${ }^{1}$ \\ ${ }^{1}$ Department of Oceanography, Dalhousie University, 1355 Oxford Street, Halifax, Nova Scotia B3H 4J1, Canada \\ ${ }^{2}$ Present address: Québec-Océan, Pavillon Vachon, Université Laval, Québec, Québec G1K 7P4, Canada
}

\begin{abstract}
We address spatial and temporal distribution of abundance, lipid and caloric content and water column energy density of the copepod Calanus finmarchicus, a major food source for the north Atlantic right whale (NARW) Eubalaena glacialis in a primary feeding habitat - Grand Manan Basin, Bay of Fundy. The focus is on the lipid-rich diapausing copepodite stage 5 (C5) that dominates the zooplankton community during the summer and autumn whale-feeding period. We show that from May through July 2002, monthly averages of depth-integrated zooplankton wet biomass $\left(<0.5 \mathrm{~g} \mathrm{~m}^{-3}\right)$ and $\mathrm{C} 5$ concentration $\left(<160 \mathrm{~m}^{-3}\right)$, copepodite energy content $(<2.5 \mathrm{~J})$ and gross energy density $\left(<0.5 \mathrm{~kJ} \mathrm{~m}^{-3}\right)$ are low and reach their maxima $\left(1.23 \mathrm{~g} \mathrm{~m}^{-3}, 870 \mathrm{~m}^{-3}, 3.5 \mathrm{~J}\right.$, and $3 \mathrm{~kJ} \mathrm{~m}^{-3}$, respectively) in September through October. The C5s represent the majority of the zooplankton and $84 \%$ of total zooplankton energy density is attributable to the wax ester content of C5s, of which there are 2 and perhaps 3 generations annually. Using right whale sighting per unit effort data in 2002, it is readily apparent that the whales occupy the Grand Manan feeding habitat in direct proportion $\left(\mathrm{r}^{2}>0.88\right.$, $\mathrm{p}<0.05$ ) to the abundance and quality (i.e. energy density) of food available in the habitat. Thus, a water column-integrated energy density of $3 \mathrm{~kJ} \mathrm{~m}^{-3}$ appears to be a reasonable minimum estimate of that needed to define a right whale feeding habitat, though subject to spatial and temporal variation. Accordingly, inter-annual variation in the abundance and energy content of C5s will influence right whale feeding success and may influence arrival at and departure to and from, as well as seasonal residency in, primary feeding habitats. We suggest that prey field examinations and estimates of the type presented here should advance insights concerning the nature and location of other potential habitats as well as variation in right whale condition and reproductive capacity.
\end{abstract}

KEY WORDS: Right whale $\cdot$ Calanus finmarchicus $\cdot$ Copepod $\cdot$ Lipid $\cdot$ Energy content $\cdot$ Prey field Resale or republication not permitted without written consent of the publisher

\section{INTRODUCTION}

Calanus finmarchicus, a ubiquitous, herbivorous calanoid copepod in the Northwest Atlantic (Conover et al. 1995, Planque et al. 1997), constitutes the primary food of many marine fish, birds and mammals (Kane 1984, Brown \& Gaskin 1988), including the critically endangered North Atlantic right whale (NARW) Eubalaena glacialis (Kraus 1985, Stone et al. 1988). It is axiomatic that spatial and temporal variations in $C$. finmarchicus abundance will influence the spatial and temporal distribution, feeding success and condition of higher trophic level consumers that depend on this species (Conover et al. 1995, Corten 2000).

Calanus finmarchicus is presumably adapted to seasonal variations in food supply through the diapausing copepodite stage 5 (C5) that rests at depth, typically $>200 \mathrm{~m}$, where it survives on lipid reserve-mainly wax esters (Hirche 1996). In late winter C5s emerge from diapausing in deep basins, moult to adult, reproduce and generate as many as 3 generations $\mathrm{yr}^{-1}$ (McLaren \& Corkett 1984, McLaren et al. 1989, 2001, 
Herman et al. 1991). As neither the onset nor duration of diapause is necessarily synchronous among individuals, C5s can accumulate at depth over protracted periods (Hirche 1996).

Annually, $33 \%$ or more of NARW species feed at depth in the Grand Manan Basin in the lower Bay of Fundy during summer and autumn (Schaeff et al. 1993), where their prey field is dominated by diapausing Calanus finmarchicus (Murison \& Gaskin 1989, Baumgartner et al. 2003a). The whales are typically resident in the Basin over the July though October period, although some arrive as early as May and depart as late as November (Kraus et al. 1982, Winn et al. 1986, Murison \& Gaskin 1989, Gaskin 1991). As close to half of the species migrate to one or more unknown and presumed feeding habitats during summer, identifying the location of such habitats remains a challenge.

It has been postulated that variations in the spatial and temporal distribution, body condition and reproductive rate (Clapham \& Cole 1999, Kraus et al. 2001) of the NARW are a function of variation in the distribution, abundance and quality of their prey (Caswell et al. 1999, Kenney 2001), though the information suitable for testing such postulates is indirect at best. For example, in the 1990s, the calving interval of the Bay of Fundy sub-population of the NAWR increased from 3 to 6 yr (Kraus et al. 2001), concomitant with changes in the occupancy of their primary (known) summerautumn feeding habitats. Beginning in 1993, right whales abandoned the Roseway Basin (Scotian Shelf) habitat and identified whales normally associated with Roseway were observed in the Grand Manan Basin along with right whales that typically migrate into the latter habitat on an annual basis (Clapham \& Cole 1999, Kenney 2001).

The above observations led us to ask how much of the variation in the abundance and quality of the right whale prey field might explain the spatial and temporal distribution, feeding success, condition and reproductive success of right whales. To address such questions, variation in the prey field population dynamics, abundance and quality must be quantified, at least at a seasonal scale that circumscribes the whale-feeding period in the feeding habitat. The population dynamics (abundance, size, generation etc.) of Calanus finmarchicus in other feeding habitats such as the Gulf of Maine (e.g. Durbin et al. 1995, Wishner et al. 1995, Meise \& O'Reilly 1996) are reasonably well documented, and recently DeLorenzo Costa et al. (2006) examined the seasonal variation in NARW zooplankton carbon:nitrogen ratio in Cape Cod Bay. However, there is a paucity of comprehensive determinations of seasonal dynamics of $C$. finmarchicus, the $\mathrm{C} 5 \mathrm{~s}$, and their quality in the
Bay of Fundy, arguably a critical feeding habitat frequented by the largest numbers of right whales over a protracted (nominally $4 \mathrm{mo}$ ) resident feedingperiod.

Consequently, our objective is to quantify monthly variation in the Calanus finmarchicus prey field in terms of abundance, stage and size, quality (energy content) and generation number in the Grand Manan Basin during the summer and autumn, when right whales are well documented to be feeding in the Basin. Our primary focus is on the lipid-rich C5 stage and on addressing the general working hypothesis that the period of maximum abundance of the NARW in the Basin habitat should coincide with the period of maximum energy available in the prey field. Our secondary focus is to determine how prey field variation in such a habitat might be used to further address questions concerning the nature and location of other potential habitats, variation in NARW arrival, departure and occupancy of known feeding habitats, and whale condition and reproductive capacity.

\section{MATERIALS AND METHODS}

Sampling. Zooplankton was collected on 5 occasions in the Grand Manan Basin during May through October 2002 (Fig. 1, Table 1). Collections in May, July, August and October relied on the vessel CCG 'Hart' and two $333 \mu \mathrm{m}$-mesh nets mounted on a $60 \mathrm{~cm}$ diameter BONGO frame (Posgay \& Marak 1980) towed at a nominal $1 \mathrm{~m} \mathrm{~s}^{-1}$ and equipped with G.O. ${ }^{\circledR}$ mechanical flowmeters (to estimate volume sampled) and a temperature and depth recorder (TDR, Vemco $\left.{ }^{\circledR}\right)$. The BONGO was towed in a double-oblique manner from the surface to $\sim 10 \mathrm{~m}$ above bottom and back to the surface. Water column temperature and salinity profiles were recorded at selected sampling stations using a Seabird-25 ${ }^{\circledR}$ CTD in every month except May (only TDR data available). Zooplankton collected at each station with one net was filtered through a $333 \mu \mathrm{m}$ mesh sieve and preserved in $4 \%$ buffered formalin. The remaining net collection was filtered as above and between 5 and $14 \mathrm{ml}$ of zooplankton was sub-sampled and immediately preserved in liquid nitrogen and later transferred to a $\leq-70^{\circ} \mathrm{C}$ freezer.

Collections in September relied on the vessel CAVF 'Quest' and BIONESS (Bedford Institute of Oceanography Net and Environment Sensing System; Sameoto et al. 1980) gear towed at a nominal $1 \mathrm{~m} \mathrm{~s}^{-1}$ and equipped with six $333 \mu \mathrm{m}$-mesh nets $\left(1 \mathrm{~m}^{2}\right.$ opening; $1.5 \mathrm{~m}$ length) that allowed for depth-integrated and depth-specific sampling of the water column. Only those collections from the first net that sampled obliquely from the surface to $\sim 10 \mathrm{~m}$ above bottom are 

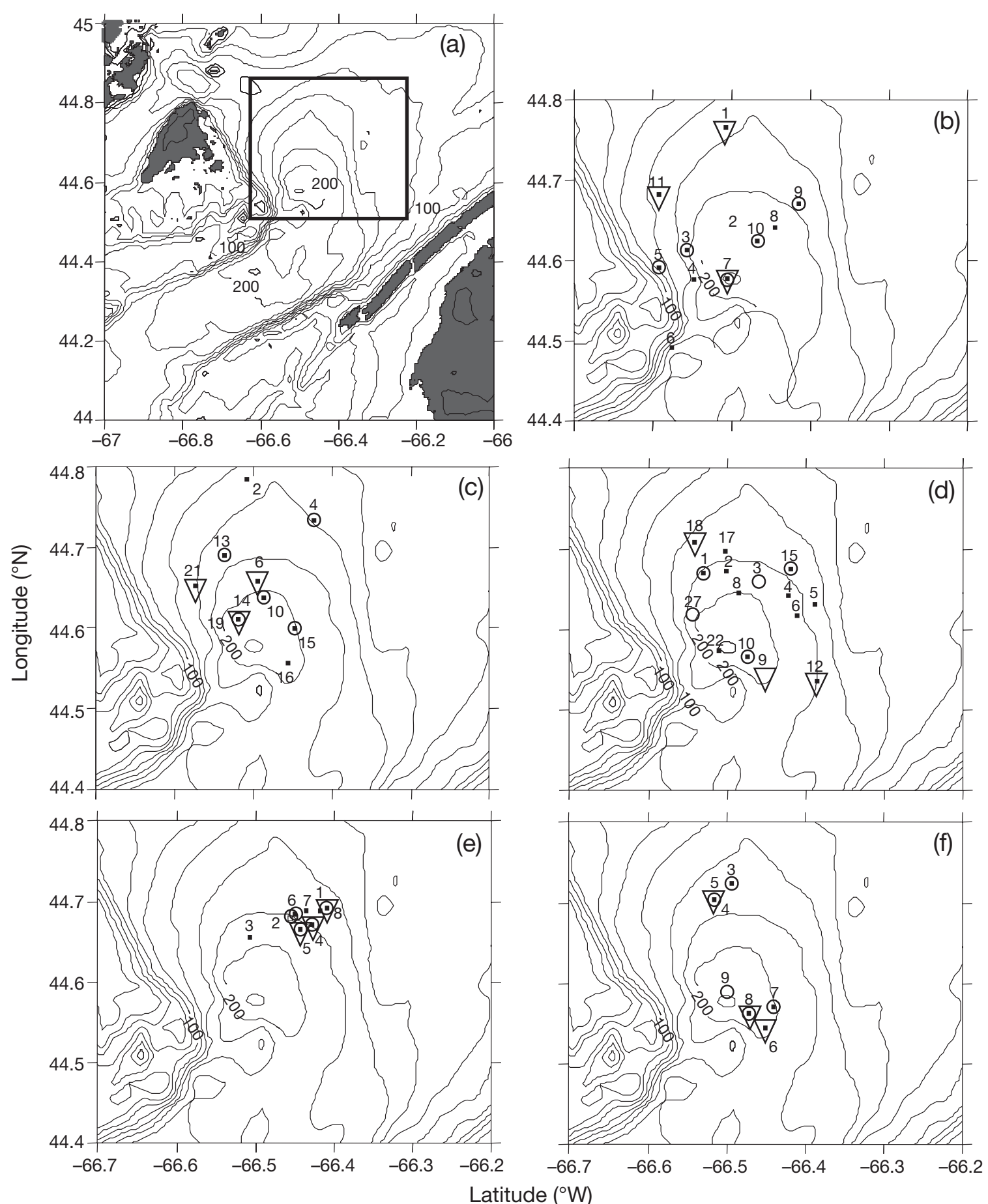

Fig. 1. Bathymetric (20 m resolution) charts of Grand Manan Basin, Bay of Fundy showing (a) the right whale conservation area (black box) and zooplankton collection stations occupied in (b) May, (c) July, (d) August, (e) September, and (f) October 2002 and those used to estimate zooplankton concentration (squares), copepod lipid content (circles), copepod total energy content (triangles). Numbers on charts indicate station identifiers

used here as it was the only net deployed in a manner similar to the BONGO deployments in other months. The BIONESS was outfitted with a Seabird-19 ${ }^{\circledR}$ CTD and 2 G.O. ${ }^{\circledR}$ flowmeters (to estimate volume sampled). Each net collection was filtered as above, a $5 \mathrm{ml}$ sub- sample was preserved in liquid nitrogen as above and the remainder was preserved in $4 \%$ buffered formalin. Temperature and salinity profiles were recorded as above at 6 of the 8 stations and immediately prior to BIONESS deployment (Table 1). 
Table 1. Summary of zooplankton sample collection details and associated water mass characteristics for May through October 2002 in the Grand Manan Basin region. na: not applicable

\begin{tabular}{|c|c|c|c|c|c|}
\hline Descriptor & May & July & August & September & October \\
\hline $\begin{array}{l}\text { Sampling period } \\
\text { (d, UTC) }\end{array}$ & $29-30$ & $10-13$ & $20-26$ & $11-14$ & $24-25$ \\
\hline $\begin{array}{l}\text { Sampling time range } \\
\text { (h, UTC) }\end{array}$ & $10-18$ & $11-18$ & $11-18$ & $1-21$ & $12-20$ \\
\hline $\begin{array}{l}\text { Sampling location range } \\
\left(\text { decimal }{ }^{\circ} \mathrm{N}\right)\end{array}$ & $44.49-44.76$ & $44.56-44.79$ & $44.54-44.71$ & $44.65-44.70$ & $44.55-44.73$ \\
\hline $\begin{array}{l}\text { Sampling location range } \\
\left(\text { decimal }{ }^{\circ} \mathrm{W}\right)\end{array}$ & $66.42-66.59$ & $66.42-66.57$ & $66.39-66.54$ & $60.50-66.45$ & $66.45-67.44$ \\
\hline $\begin{array}{l}\text { Range in sampling } \\
\text { tow-time (min:s) }\end{array}$ & $08: 30-22: 00$ & 09:05-16:59 & $08: 25-18: 50$ & 05:06-10:10 & $11: 30-15: 10$ \\
\hline $\begin{array}{l}\text { Range in depth of } \\
\text { thermocline }(\mathrm{m})\end{array}$ & $20-50$ & $15-30$ & $15-45$ & $25-50$ & $40-150$ \\
\hline $\begin{array}{l}\text { Temperature range above } \\
\text { thermocline }\left({ }^{\circ} \mathrm{C}\right)\end{array}$ & $6.7-10.1$ & $8.3-13.1$ & $9.6-15.4$ & $10.5-13.3$ & $10.9-11.2$ \\
\hline $\begin{array}{l}\text { Temperature range below } \\
\text { thermocline }\left({ }^{\circ} \mathrm{C}\right)\end{array}$ & $6.4-7.8$ & $7.3-9.8$ & $8.9-13.9$ & $9-12.8$ & $10.8-11.2$ \\
\hline $\begin{array}{l}\text { Salinity range above } \\
\text { thermocline }\end{array}$ & na & $30.7-32.5$ & $32-33.1$ & $32.6-33.5$ & $33.2-33.7$ \\
\hline $\begin{array}{l}\text { Salinity range below } \\
\text { thermocline }\end{array}$ & na & $32.1-33.2$ & $32.5-33.8$ & $32.75-33.9$ & $33.4-33.9$ \\
\hline $\begin{array}{l}\text { No. stations for estimating } \\
\text { zooplankton concentration }\end{array}$ & 11 & 9 & 14 & 8 & 7 \\
\hline No. stations for lipid analyses & 5 & 5 & 5 & 6 & 5 \\
\hline $\begin{array}{l}\text { No. stations for calorimetric } \\
\text { analyses }\end{array}$ & 3 & 3 & 3 & 4 & 3 \\
\hline
\end{tabular}

Zooplankton taxonomic and abundance analysis. The wet biomass $\left(\mathrm{g} \mathrm{m}^{-3}\right)$ of zooplankton collected at each station was estimated using the formalinpreserved BONGO net collections and the formalinpreserved plus frozen sub-samples from the BIONESS collections. All large and rare organisms (macrozooplankton; nominally $>1 \mathrm{~cm}$ ) were sorted from the formalin-preserved BONGO and BIONESS collections, identified to family, and counted (BIONESS collections proportionally adjusted for the frozen sub-sample). The remainder (mesozooplankton; nominally $333 \mu \mathrm{m}$ to $1 \mathrm{~cm}$ ) was partitioned using a Folsom splitter (McEwen et al. 1954) until replicate sub-samples (150 to 200 copepods) were obtained. All zooplankton in sub-samples were counted and identified: copepodites to genus, species and stage and the others to the highest taxonomic resolution possible. Sequential replicate sub-samples were examined until the coefficient of variation $(\mathrm{CV})$ for both the dominant copepod species and stage and the total number of copepods either decreased to $\sim 10 \%$ or less, or stabilized, or until a maximum of 6 sub-samples had been examined $(7$ examined in one collection). Generally 3 to 4 replicates were required for both BONGO and BIONESS collections and the average CV for the total number of copepods and $\mathrm{C} 5 \mathrm{~s}$ consistently ranged between 10 and $11 \%$. These procedures provided uncertainties in the zooplankton abundance estimates.
Calorimetric analyses. Gross energy content (caloric) of C5s was determined using a Parr ${ }^{\circledR} 1266$ semi-micro oxygen-bomb calorimeter. As instrument sensitivity did not allow for the analysis of individual C5s, a sample consisted of $\sim 20$ individuals. Three station collections per month were selected for analysis, and for each collection, 3 sub-samples of the frozen C5s were sorted into 3 prosome length (PrL) classes of $\sim 20$ individuals each (total of 9 sub-samples per station). The PrL classes, determined from the first and third quartiles of the normal length distribution of individual C5s measured using a dissecting microscope and an ocular micrometer, were: $<2.23 \mathrm{~mm}$ (small), $\geq 2.23$ and $\leq 2.49 \mathrm{~mm}$ (intermediate), and $>2.49 \mathrm{~mm}$ (large). All samples were kept on ice prior to and during sorting and only undamaged individuals (i.e. no evidence oil leakage) were selected. All samples were wet-weighed and freeze-dried for $8 \mathrm{~h}$ using a Labconco ${ }^{\circledR} 4.5 \mathrm{~L}$ freeze-dryer. After drying, the samples were dry-weighed on a Perkin-Elmer ${ }^{\circledR}$ AD-4 autobalance $(0.0000 \mathrm{mg})$. Each replicate sample (nominally $0.01 \mathrm{~g}$ ) was compressed to a $3 \mathrm{~mm}$-diameter pellet.

Pellets were combusted using 1 of 2 Parr ${ }^{\circledR} 1107$ micro-bombs; each calibrated using 5 sequential combustions of $0.2 \mathrm{~g}$ benzoic acid pellets (Versicol). Calibrations were checked and adjusted as needed by burning one benzoic acid pellet for every 10 samples burned, where station sample replicates were burned 
in random order. A known weight of benzoic acid was added (spike) to each C5 pellet to help ensure that the combustion rise in temperature $\left(\Delta T_{;}{ }^{\circ} \mathrm{C}\right)$ was comparable to the calibration $\Delta T$. Gross heat of combustion, or gross energy content, (cal $\mathrm{g}^{-1}$ dry weight) was corrected for ignition (2.3 $\mathrm{cal} \mathrm{cm}^{-1}$ burned fuse). There was no correction for the negligible heat-offormation of nitric acid from residual atmospheric nitrogen in the bomb (10 replicates of benzoic acid pellet combustion consistently revealed $<0.03 \mathrm{cal}$ of the $\sim 1260$ cal produced was related to nitric acid formation). Heat-of-formation of sulphuric acid from the combustion of biological material was considered negligible and ignored. Dry weight-specific gross energy content is expressed as $\mathrm{kJ} \mathrm{g}^{-1}$ using a conversion factor of $4.1868 \mathrm{~J} \mathrm{cal}^{-1}$. Gross energy content $\left(E C_{i} J\right)$ is the product of the dry weight-specific gross energy content and sample pellet freeze-dried weight divided by the number of copepods in the sample.

Estimates of energy content that are less than the minimum heat of combustion expected for biological material (17.6 kJ $\mathrm{g}^{-1}$ ash-free dry weight, AFDW) should be considered suspect (Lamprecht 1999). Accordingly, AFDW energy content was calculated for all C5 samples assuming an ash-content of $10 \%$ (determined from ash weight of bulk-mixed samples). Fourteen samples with AFDW energy content $<17.6 \mathrm{~kJ} \mathrm{~g}^{-1}\left(<15.8 \mathrm{~kJ} \mathrm{~g}^{-1}\right.$ dry weight-specific energy content) were excluded along with 4 extremely high statistical outliers.

Lipid analyses. Between 5 and 8 station collections per month were selected for lipid analysis and between 10 and 30 C5s were sorted from each frozen zooplankton sub-sample and used for individual lipid content analysis (Table 1). As above, all samples were kept on ice prior to and during sorting and only undamaged individuals (i.e. no evidence of oil leakage) were selected. Prior to lipid extraction each C5 was photographed (on ice) using a Kodak MegaPlus ${ }^{\circledR}$ camera (Model 4.1) and dissecting microscope. Images captured using Xcap-Lites ${ }^{\circledR}$ (version 2.2, Epix 1999) were used to measure PrL using SigmaScan Pro ${ }^{\circledR}$ (Version 5.0.0, SPSS 1999).

Quantification of wax esters (WE), triacylglycerols (TAG), sterol (ST) and polar lipids (PL) relied on thin
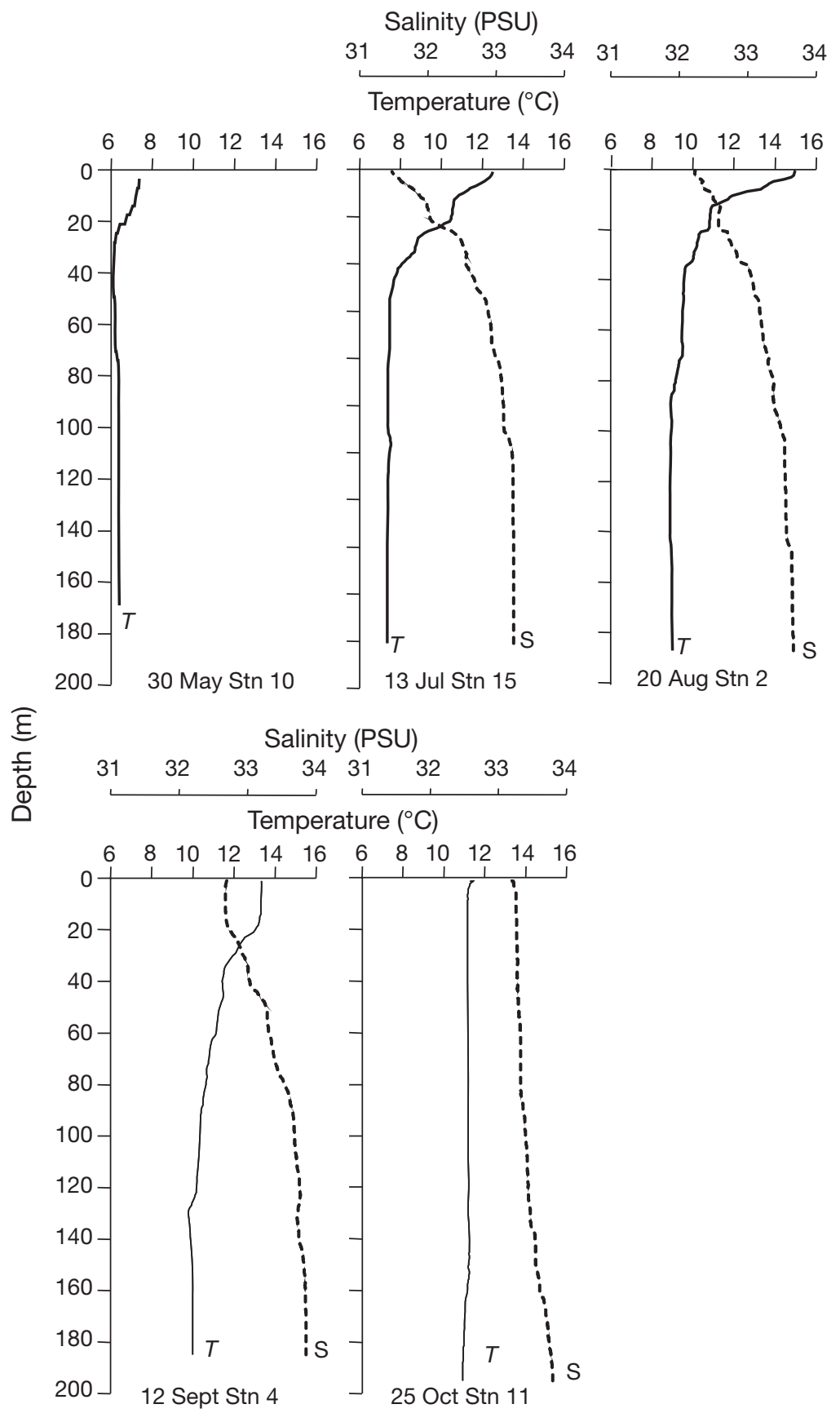

Fig. 2. Typical temperature $\left(T_{;}{ }^{\circ} \mathrm{C}\right.$, solid) and salinity (S, dashed) depth (m) profiles among several stations (see Fig. 1) and several days in the Grand Manan Basin associated with zooplankton sampling from May through October 2002. Temperature, salinity and thermocline depth ranges among all 46 stations over the sampling period are provided in Table 1

layer chromatography and flame ionization detection (TLC-FID) using an Iatroscan ${ }^{\circledR}$ Mark-V. Each C5 was placed in a $1 \mathrm{ml}$ solvent solution of dichloromethane:methanol $(2: 1, \mathrm{v}: \mathrm{v})$ with a known volume of nonadecanol (Aldrich 286842), and stored at $-20^{\circ} \mathrm{C}$ for $24 \mathrm{~h}$. Lipids were then extracted following Bligh \& 
Dyer (1959) as adapted by Ohman (1988). Lipid extracts were spotted on rack-mounted Chromarods ${ }^{\circledR}$, dried (5 min over a hot plate) and then humidified for 5 min over a saturated $\mathrm{CaCl}_{2}$ solution. Lipid classes were separated using a double elution solvent scheme (Ohman 1988, Miller et al. 1998). Briefly, rods were held for $35 \mathrm{~min}$ in a saturated hexane:ethyl ether (76:4 v:v) atmosphere, dried, humidified as above and held for $20 \mathrm{~min}$ in a saturated hexane:ethyl ether:formic acid (66:14:0.1 v:v:v) atmosphere. Rods were dried, placed in the Iatroscan and scanned at a rate of $40 \mathrm{~s}$ $\operatorname{rod}^{-1}$ using $160 \mathrm{ml} \mathrm{min}^{-1}$ hydrogen and $2000 \mathrm{ml} \mathrm{min}^{-1}$ air flow.

Lipid class content for each C5 was estimated using calibration curves of commercial standards and inverse prediction (Sokal \& Rohlf 1981) where the standards were palmitic acid stearyl ester for WE (Sigma P-3512), tripalmitin for TAG (Sigma T-5888), cholesterol ST (Sigma C-8667), and L- $\alpha$-phosphatidylcholine dipalmitoyl for PL (Sigma P-4329). Individual reserve lipid (RES) is the sum of WE and TAG and total individual lipid (TOT) is the sum of the 4 classes. The internal standard, 1-nonadecanol (NONA, Aldrich 286842) was used in both the standard mixture and in the copepod lipid extract to correct for lipid loss during extraction and spotting.

Estimation of gross and lipid energy density. The C5 concentration $\left(\mathrm{m}^{-3}\right)$, PrL size-class distribution each month, individual EC and lipid content $(\mu \mathrm{g})$ were used to estimate the gross and lipid energy density $\left(\mathrm{kJ} \mathrm{m}^{-3}\right)$ available at each station. The gross energy density $\left(\mathrm{kJ} \mathrm{m}^{-3}\right)$ for each $\mathrm{C} 5$ size-class at each station is the product of the concentration of each PrL class and the individual EC within the class. Variance in gross energy density was estimated as the sum of the variance in the C5 concentration and the variance in the C5 EC. Covariance was ignored by reasonably assuming that fluctuations in concentration and the gross energy content are not correlated (Bevington \& Robinson 2003). Variance in individual EC was estimated as the sum of the variance among and within samples, where the latter is the calorimeter machine error $\left(12.6 \mathrm{~J}^{\circ} \mathrm{C}^{-1}\right.$ representing $<1 \%$ of standard benzoic acid combustion) for each calorific estimate. A similar procedure was used to estimate the lipid density $\left(\mu \mathrm{g} \mathrm{m}^{-3}\right)$ as the product of the concentration of each C5 PrL class and individual lipid content (for WE and TOT only), where variance in lipid density was estimated as the sum of the variance in C5 concentration and the variance in the C5 lipid class content. Variance in individual lipid class content was estimated using the individual lipid class estimates and the prediction error from the standard calibration curves. WE and TOT density were converted to WE and TOT energy density (kJ $\mathrm{m}^{-3}$ ) using a conversion factor of $39.5 \mathrm{~kJ} \mathrm{~g}^{-1}$ of lipid
(Lamprecht 1999). Monthly means of both gross and lipid energy density were estimated and the variance within stations was added to the variance among stations to obtain total variance.

The majority of statistical analyses rely on analysis of variance (ANOVA; p-values provided except where otherwise noted) where all data were tested for normality and transformed (normalized) when required and if so the geometric mean is provided. A posteriori comparisons relied on the Tukey-Kramer 'honestly significant difference' test (HSD) with $\alpha=0.05$. Significant digits are provided in accord with convention.

\section{RESULTS}

\section{Hydrography at zooplankton sampling stations}

The water column in the Grand Manan Basin progressed from slightly stratified to stratified and then to well mixed from May through October 2002 with the thermocline varying between 5 and $50 \mathrm{~m}$ depth (Table 1, Fig. 2). A weak thermocline was sometimes observed between 130 and $150 \mathrm{~m}$ in September and October (Fig. 2). The surface layer warmed between May $\left(7.1\right.$ to $13.1^{\circ} \mathrm{C}$ ) and August (11.0 to $\left.15.4^{\circ} \mathrm{C}\right)$, cooled in September $\left(10.5\right.$ to $\left.13.3^{\circ} \mathrm{C}\right)$ and became uniform in October $\left(10\right.$ to $\left.11^{\circ} \mathrm{C}\right)$. Water below the thermocline warmed from $6.4^{\circ} \mathrm{C}$ in May to $12.8^{\circ} \mathrm{C}$ in September and October. The water column was more saline in August through October than in earlier months.

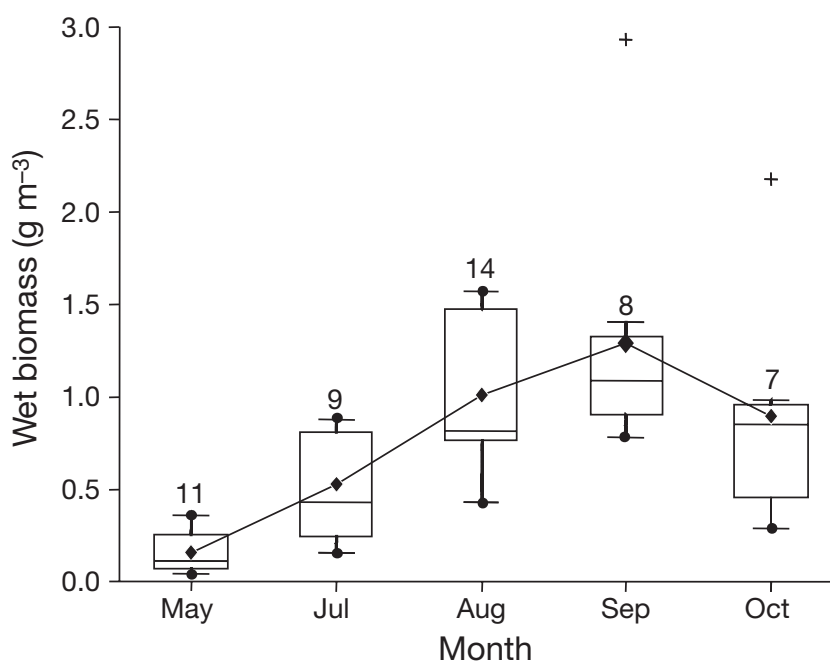

Fig. 3. Box and whisker summary of depth-integrated estimates of zooplankton wet biomass $\left(\mathrm{g} \mathrm{m}^{-3}\right)$ in the Grand Manan Basin from May through October 2002. The box and line represent the lower quartile, median, and upper quartile, the diamonds represent the mean, and the whiskers represent $1.5 \times$ the inter-quartile range with outliers represented by crosses, absence of outliers by dots on the whisker. Numbers over box: no. of collections for each month 


\section{Monthly patterns in zooplankton biomass, composition and abundance}

Depth-integrated (water column) zooplankton wet biomass (macro- and mesozooplankton) increased from a minimum in May to a maximum in September (Fig. 3). Average zooplankton wet biomass was lower $\left(\mathrm{p}<0.000\right.$, HSD) in May $\left(0.15 \mathrm{~g} \mathrm{~m}^{-3}\right)$ and July $(0.48 \mathrm{~g}$ $\mathrm{m}^{-3}$ ) than in August $\left(0.97 \mathrm{~g} \mathrm{~m}^{-3}\right)$, September (1.23 $\mathrm{g}$ $\left.\mathrm{m}^{-3}\right)$ and October $\left(0.81 \mathrm{~g} \mathrm{~m}^{-3}\right)$.

Concentrations of macrozooplankton species showed limited variation over the sampling period and euphausiids dominated the macro species in all months with an average concentration that never exceeded $0.57 \mathrm{~m}^{-3}$ (Table 2). Copepods dominated the mesozooplankton in all months and Calanus finmarchicus was most prevalent with average water column concentration increasing from $39 \mathrm{~m}^{-3}$ in May to $1017 \mathrm{~m}^{-3}$ in September, with a slight decline thereafter. C. finmarchicus represented $79 \%$ of individual zooplankters in May and $\sim 95 \%$ in September and October. Concentrations of C. hyperboreus, C. glacialis, and Euchaeta norvegica did not exceed $10 \mathrm{~m}^{-3}$.

Most of the monthly variation in total zooplankton wet biomass is attributable to variation in Calanus finmarchicus $\mathrm{C} 5$ concentration (Fig. 4). The concentration of females, males and C5s were similar in May and as the season progressed C5 concentration increased by 2 orders of magnitude (Fig. 4a) while female (Fig. 4b) and male (Fig. 4c) concentrations tripled, at best. Con-

Table 2. Monthly mean concentrations $\left(\mathrm{m}^{-3}\right)$ and standard deviation (SD) of major zooplankton taxa over the period May through June 2002 in the Grand Manan Basin. -: non observed

\begin{tabular}{|c|c|c|c|c|c|c|c|c|c|c|}
\hline \multirow[t]{2}{*}{ Taxa } & \multicolumn{2}{|c|}{ May } & \multicolumn{2}{|c|}{ July } & \multicolumn{2}{|c|}{ August } & \multicolumn{2}{|c|}{ September } & \multicolumn{2}{|c|}{ October } \\
\hline & Mean & $\mathrm{SD}$ & Mean & $\mathrm{SD}$ & Mean & $\mathrm{SD}$ & Mean & $\mathrm{SD}$ & Mean & $\mathrm{SD}$ \\
\hline \multicolumn{11}{|l|}{ Macrozooplankton } \\
\hline Euphasiid & 0.07 & 0.07 & 0.08 & 0.07 & 0.04 & 0.06 & 0.57 & 0.85 & 0.07 & 0.04 \\
\hline Pandalidae & 0.001 & 0.002 & 0.01 & 0.01 & 0.01 & 0.02 & 0.01 & 0.01 & 0.01 & 0.01 \\
\hline Amphipod & - & - & - & - & $<0.01$ & 0.01 & $<0.01$ & 0.01 & 0.01 & 0.01 \\
\hline Cnidaria & - & - & - & - & - & - & - & - & $<0.01$ & 0.01 \\
\hline Others $^{\mathrm{a}}$ & $<0.01$ & $<0.01$ & $<0.01$ & $<0.01$ & $<0.01$ & $<0.01$ & $<0.01$ & $<0.01$ & $<0.01$ & $<0.01$ \\
\hline \multicolumn{11}{|l|}{ Mesozooplankton } \\
\hline Calanus finmarchicus & 39.02 & 22.65 & 263.05 & 159.12 & 652.609 & 308.01 & 1017.21 & 647.01 & 779.94 & 531.49 \\
\hline Calanus glacialis & 1.08 & 0.95 & 3.25 & 2.53 & 6.809 & 3.422 & 6.30 & 5.49 & 0.86 & 1.36 \\
\hline Calanus hyperboreus & 2.52 & 2.36 & 9.41 & 9.87 & 7.601 & 3.617 & 6.62 & 9.93 & 1.09 & 1.55 \\
\hline Euchaeta norvegica & 0.64 & 0.88 & 1.87 & 2.26 & 3.465 & 3.937 & 3.17 & 3.62 & 0.60 & 1.11 \\
\hline Metridua lucens & 0.73 & 0.80 & 5.19 & 3.81 & 2.306 & 2.238 & 4.11 & 5.28 & 6.94 & 4.02 \\
\hline Pseudocalanus spp. & 0.99 & 1.30 & 2.33 & 2.396 & 8.916 & 7.445 & 4.69 & 4.96 & 5.05 & 4.70 \\
\hline Metridia longa & 0.60 & 0.65 & 1.39 & 2.89 & 3.808 & 3.896 & 2.54 & 2.96 & 1.25 & 2.74 \\
\hline Acartia tonsa & 0.18 & 0.32 & 0.58 & 1.17 & 7.796 & 7.457 & 3.00 & 5.70 & 0.34 & 0.57 \\
\hline Temora longicornis & 0.001 & 0.003 & - & - & 1.180 & 2.481 & 0.06 & 0.19 & 0.20 & 0.53 \\
\hline Centropages typicus & - & - & 0.01 & 0.02 & 0.329 & 0.718 & 5.70 & 9.19 & 6.11 & 11.81 \\
\hline Centropages hamatus & - & - & 0.02 & 0.05 & 1.416 & 1.813 & 0.73 & 1.64 & - & - \\
\hline Oithona similis & 0.001 & 0.004 & - & - & - & - & 0.11 & 0.32 & 0.16 & 0.42 \\
\hline Clausocalanus sp. & 0.07 & 0.13 & 1.47 & 1.41 & 0.336 & 0.750 & 0.15 & 0.46 & 1.63 & 2.03 \\
\hline Oncaea sp. & 0.004 & 0.014 & - & - & - & - & - & - & - & - \\
\hline Pleuromamma sp. & 0.01 & 0.02 & - & - & - & - & - & - & - & - \\
\hline Microcalaus sp. & 0.02 & 0.03 & - & - & 0.096 & 0.358 & - & - & - & - \\
\hline Harpacticoid & 0.001 & 0.003 & - & - & - & - & - & - & - & - \\
\hline Broken unidentifiable & 1.06 & 0.61 & 5.38 & 3.51 & 4.106 & 2.766 & 14.67 & 19.48 & 5.75 & 6.59 \\
\hline Copepod egg & 0.16 & 0.10 & 0.02 & 0.05 & 0.086 & 0.227 & 0.32 & 0.97 & - & - \\
\hline Copepod egg sac & 0.08 & 0.15 & 0.11 & 0.26 & 0.763 & 0.878 & 1.00 & 1.69 & - & - \\
\hline Euphausiid nauplii & 0.03 & 0.04 & 0.01 & 0.04 & 0.170 & 0.436 & - & - & - & - \\
\hline Euphausiid egg & 1.74 & 1.64 & 35.02 & 18.49 & 8.029 & 5.523 & 0.37 & 0.56 & - & - \\
\hline Chaetognath & 0.25 & 0.40 & - & - & 0.096 & 0.358 & 0.17 & 0.35 & 0.48 & 0.83 \\
\hline Copepod nauplii & 0.03 & 0.05 & 0.09 & 0.27 & 0.561 & 0.869 & - & - & - & - \\
\hline Cnidaria & - & - & 0.03 & 0.05 & 4.721 & 7.209 & - & - & - & - \\
\hline Gastropod larvae & 0.08 & 0.23 & 0.04 & 0.11 & - & - & - & - & 0.20 & 0.52 \\
\hline Cladoceran & - & - & - & - & 0.939 & 3.513 & - & - & - & - \\
\hline Cirriped larvae & 0.002 & 0.007 & - & & - & - & - & - & - & - \\
\hline Misc. crustaceans ${ }^{b}$ & 0.13 & 0.33 & 0.16 & $<0.01$ & 0.000 & & - & - & - & - \\
\hline Others $^{c}$ & 0.04 & 0.07 & - & - & 0.074 & 0.278 & - & - & 0.20 & 0.53 \\
\hline
\end{tabular}



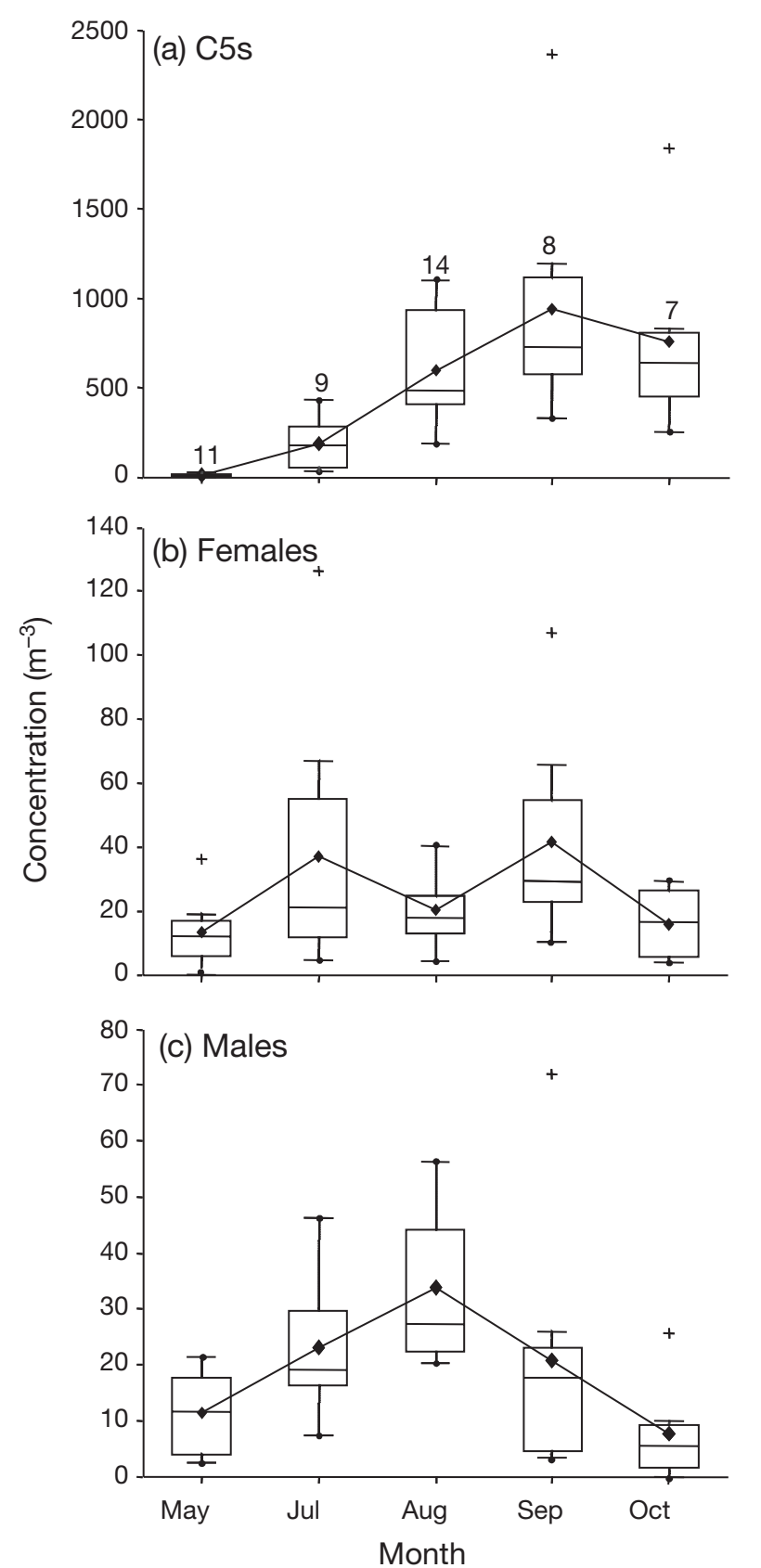

Fig. 4. Calanus finmarchicus. Box and whisker summary of depth-integrated estimates of (a) C5, (b) female, and (c) male C. finmarchicus concentration $\left(\mathrm{m}^{-3}\right)$ in the Grand Manan Basin from May through October 2002. The box and line represent the lower quartile, median, and upper quartile, the diamonds represent the mean, and the whiskers represent $1.5 \times$ the inter-quartile range with outliers represented by crosses, absence of outliers by dots on the whisker. Numbers over box: no. of collections for each month

centrations of C5s were higher ( $p<0.0001$, HSD) in September $\left(866.1 \mathrm{~m}^{-3}\right)$ than in May and July $\left(158.5 \mathrm{~m}^{-3}\right)$ but no different from either August $\left(560.8 \mathrm{~m}^{-3}\right)$ or October $\left(691.4 \mathrm{~m}^{-3}\right)$.

\section{Monthly variation in C5s length, gross energy and lipid content}

The size-frequency distribution of C5s shifted toward smaller animals from May though October (Fig. 5) with C5s in May being the largest and those in October the smallest ( $p<0.0001$; HSD).

There were no differences in the energy of combustion (cal g ${ }^{-1}$ ) among replicate C5s within length classes (Mann-Whitney p > 0.5, $\mathrm{N}=53$ ). For all 3 size-classes,
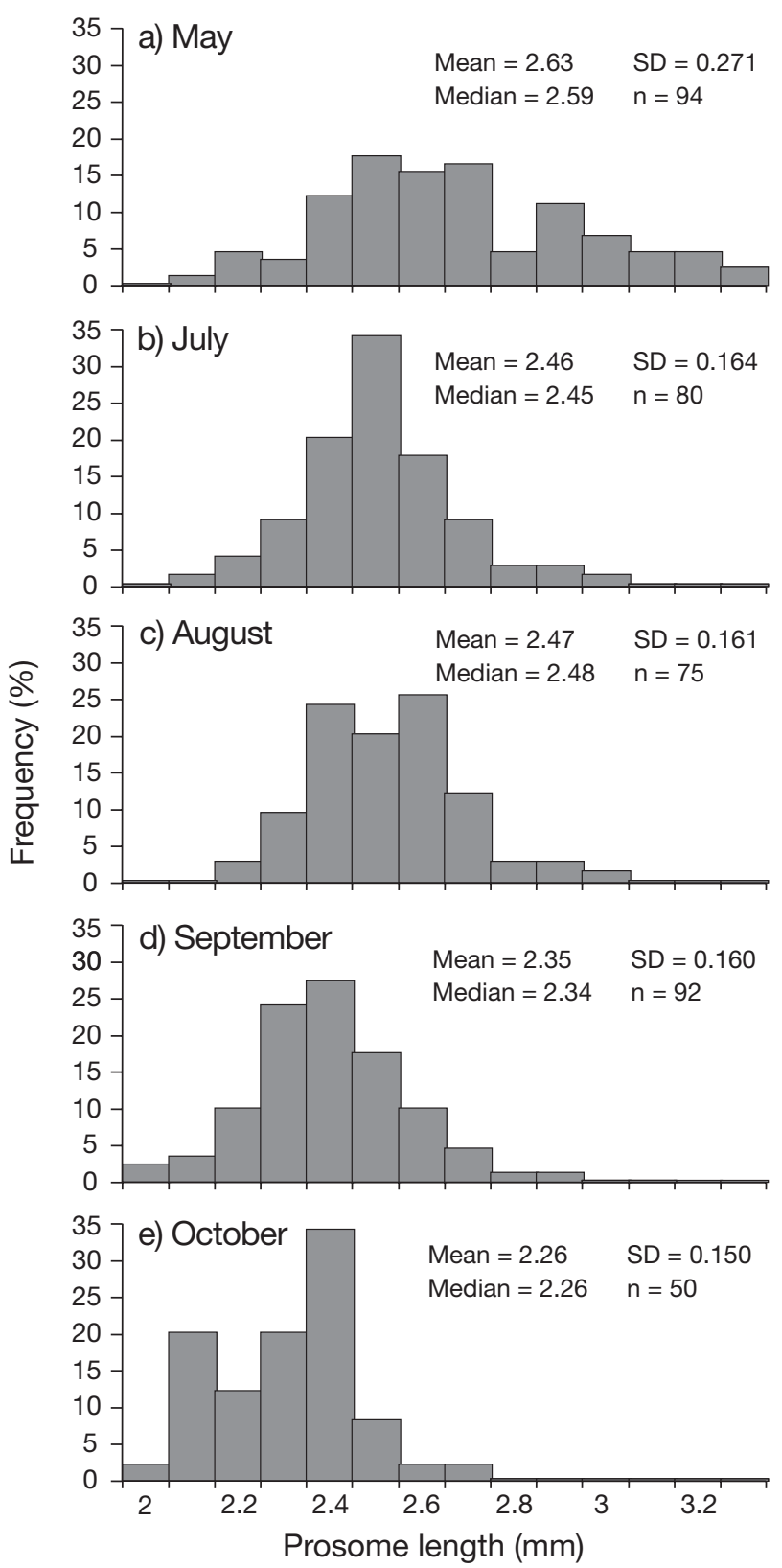

Fig. 5. Calanus finmarchicus. C5 prosome length (mm) frequency distributions and associated statistics for collections in the Grand Manan Basin during (a) May, (b) July, (c) August, (d) September, and (e) October 2002 
the C5 individual EC was normally distributed and increased from May to September, with a slight decrease in October (Fig. 6). Average EC for small C5s tripled from May to September and decreased thereafter (Fig. 6a). Average EC was lower in May and July
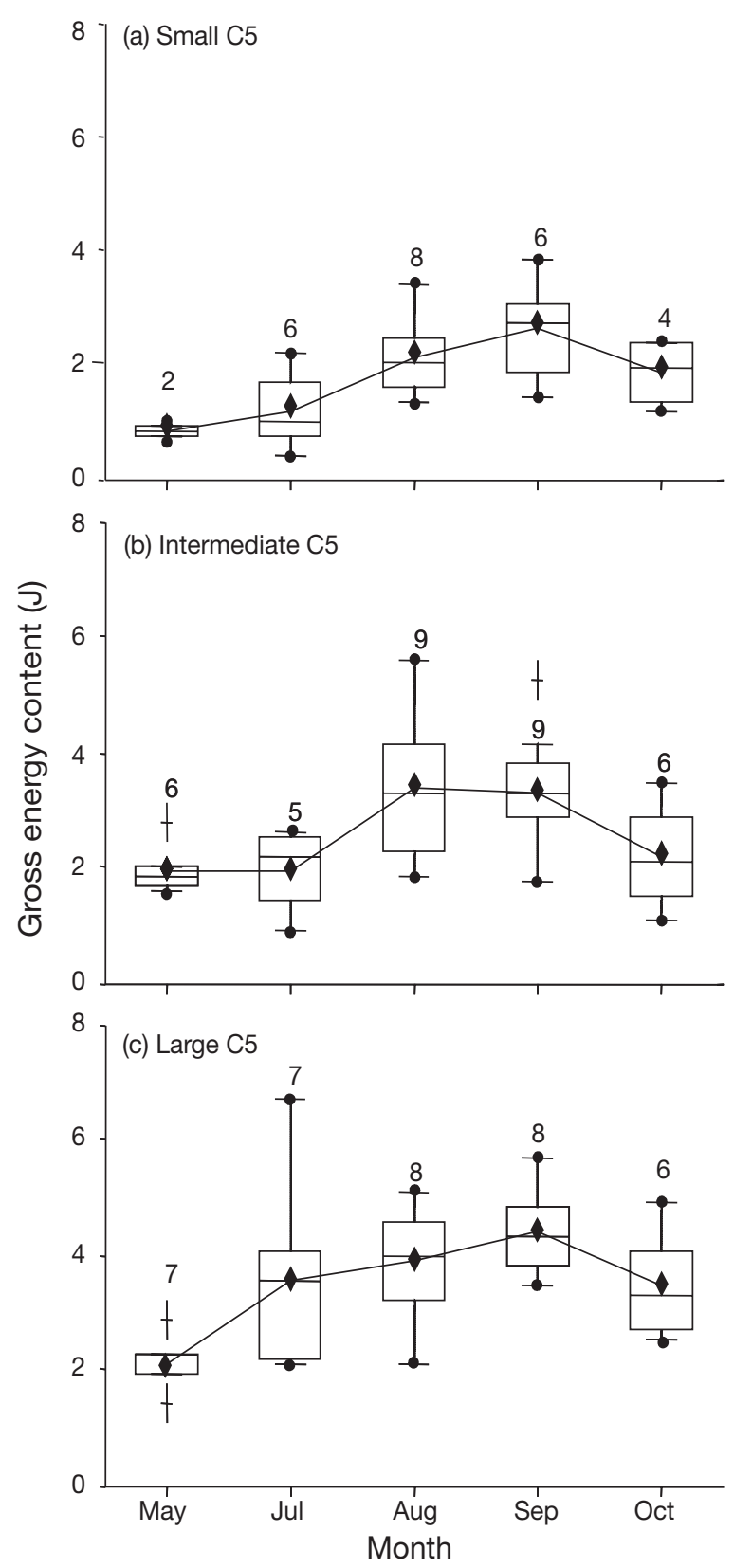

Fig. 6. Calanus finmarchicus. Box and whisker summary of depth-integrated estimates of: (a) small, (b) intermediate, and (c) large C. finmarchicus C5 individual gross energy content $(\mathrm{EC}, \mathrm{J})$ in the Grand Manan Basin from May through October 2002. The box and line represent the lower quartile, median, and upper quartile, the diamonds represent the mean and the whiskers represent $1.5 \times$ the inter-quartile range with outliers represented by crosses and absence of outliers by dots on the whisker. Numbers over box: no. of collections for each month
(1.2 J) than in September ( $p=0.01 ;$ HSD). A similar pattern was observed for intermediate C5s (Fig. 6b), where average EC in May (1.93 J) was similar to that in July and increased to $3.36 \mathrm{~J}$ in August and $3.31 \mathrm{~J}$ in September followed by a decrease in October. Although ANOVA indicated monthly differences $(\mathrm{p}=$ 0.0085), the a posteriori HSD test indicated no significant differences. The EC estimate for large C5s (Fig. 6c) in May (2.13 J) was lower than in August (3.83 J) and September (4.35 J; p =0.0036; HSD).

The dominant lipid component in individual C5s in all months was WE, followed by PL, TAG and ST in decreasing order (Fig. 7). The relative proportion of total lipids represented by WE in C5s averaged between $58 \%$ in May and $75 \%$ in October whereas the relative proportion of PL varied between 15 and $28 \%$ and showed an opposite temporal trend relative to WE. The highest relative proportion of TAG was observed in May $(12 \%)$, after which it remained at $\leq 10 \%$. The relative proportion of $\mathrm{ST}$ remained at $\leq 2 \%$ over the entire season.

With the exception of ST (low, invariant and not shown), specific individual lipid content among C5s was variable and demonstrated trends across months (Fig. 8). Individual WE increased by $\sim 50 \%$ from an average of $66.2 \mu \mathrm{g}$ in May to $92.5 \mu \mathrm{g}$ in August and remained relatively constant through to October (Fig. 8a). Average WE was $\sim 50 \%$ lower in May $(50.9 \mu \mathrm{g})$ than in the other months (73 to $86 \mu \mathrm{g} ; \mathrm{p}<$ 0.0001, HSD) among which there were no differences. There was no change in individual PL content (Fig. 8b) except in September, when the average (23.2 $\mu \mathrm{g}$ ) was higher $(\mathrm{p}<0.0001, \mathrm{HSD})$ than in May, July and October (15.1 to $16.1 \mu \mathrm{g})$ but similar to August. Monthly average individual TAG was always $\leq 10.1 \mu \mathrm{g}$

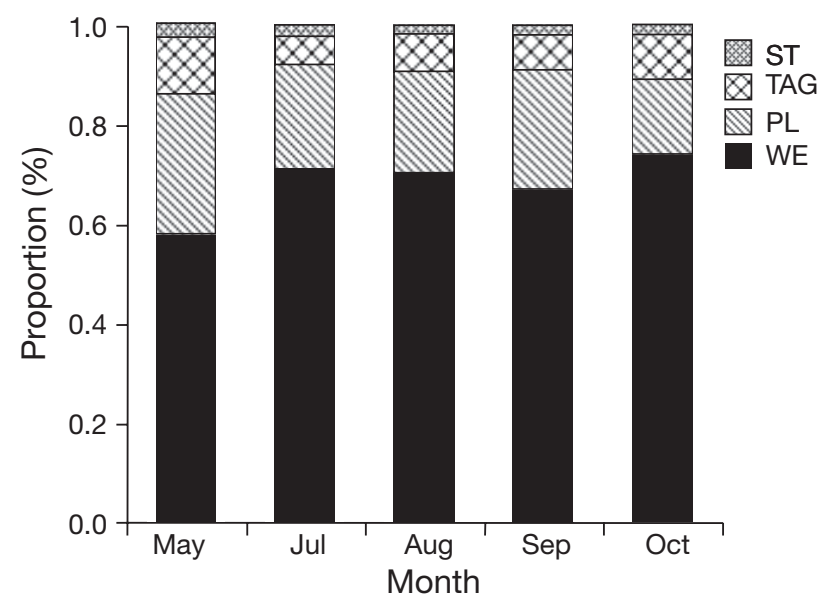

Fig. 7. Calanus finmarchicus. Monthly change in proportions of lipid components: wax esters (WE), polar lipids (PL), triacylglycerols (TAG), sterols (ST) in C. finmarchicus C5s in the Grand Manan Basin from May through October 2002 

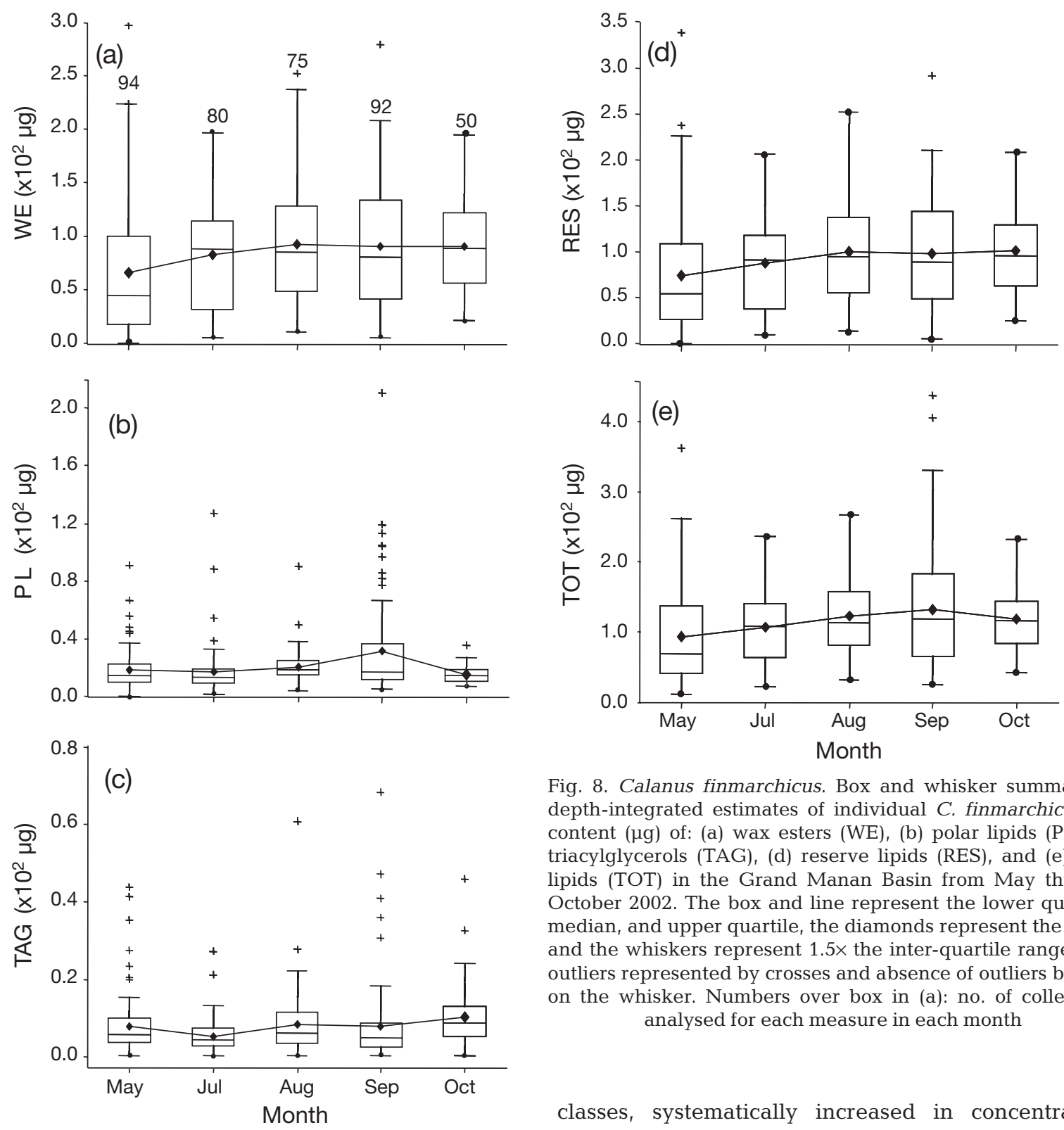

Fig. 8. Calanus finmarchicus. Box and whisker summary of depth-integrated estimates of individual C. finmarchicus C5 content $(\mu \mathrm{g})$ of: (a) wax esters (WE), (b) polar lipids (PL), (c) triacylglycerols (TAG), (d) reserve lipids (RES), and (e) total lipids (TOT) in the Grand Manan Basin from May through October 2002. The box and line represent the lower quartile, median, and upper quartile, the diamonds represent the mean and the whiskers represent $1.5 \times$ the inter-quartile range with outliers represented by crosses and absence of outliers by dots on the whisker. Numbers over box in (a): no. of collections analysed for each measure in each month

and contributed little to individual RES and TOT (Fig. 8c). Overall, variation in individual RES and TOT is principally explained by variation in WE (Fig. 8d,e) and RES and TOT increased from May to a maximum in August (RES) and September (TOT). Average RES and TOT were lower in May than in August, September and October, months among which there were no differences $(\mathrm{p}<0.0001, \mathrm{HSD})$.

\section{Monthly variation in gross and lipid energy density}

The right whale prey field, represented by the small, intermediate and large C5s and their combined size-

classes, systematically increased in concentration, individual gross energy content (EC) and gross energy density from May to September and declined in October (Fig. 9). The maximum depth-integrated concentration $\left(221.6 \mathrm{~m}^{-3}\right)$ of small C5s was observed in October (Fig. 9a) and their highest EC (2.72 J) was observed in September (Fig. 9c) with gross energy density estimates in September $\left(0.54 \mathrm{~kJ} \mathrm{~m}^{-3}\right)$ and October $\left(0.40 \mathrm{~kJ} \mathrm{~m}^{-3}\right)$ not different from each other, though each estimate was higher than in all the other months (Fig. 9e, p < 0.0001, HSD). Intermediate C5s (Fig. 9a) provided a gross energy density of $1.74 \mathrm{~kJ} \mathrm{~m}^{-3}$ in September (Fig. 9e) that was higher than other months $(\mathrm{p}<$ 0.0001, HSD; Fig. 9c). Intermediate C5 gross energy density in August and October was higher than in May and July. The EC for large C5s was highest in September (4.31 J; Fig. 9c) while highest C5 concentration 

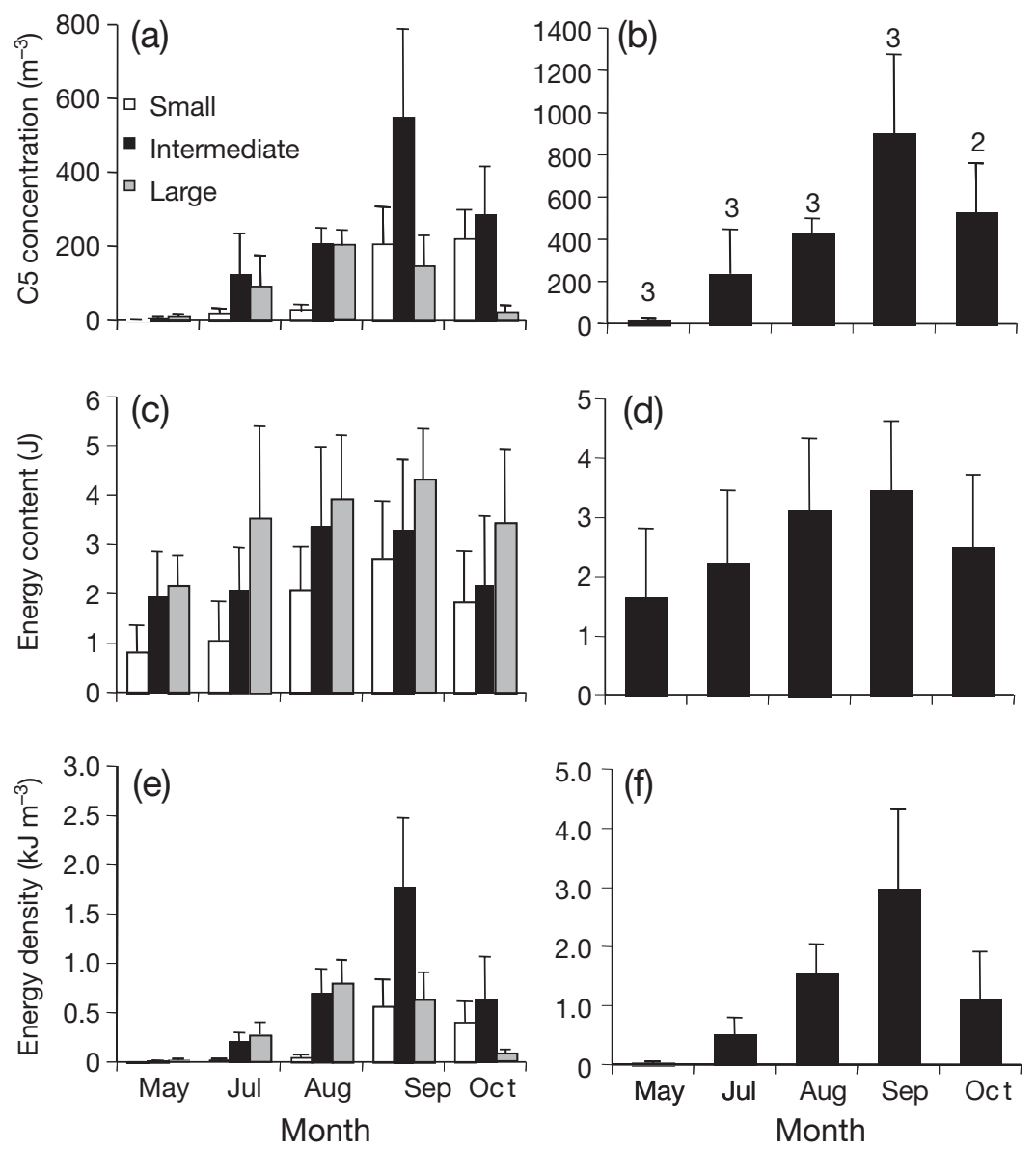

Fig. 9. Calanus finmarchicus. Histograms illustrating changes in monthly average $(+2 \mathrm{SE})$ estimates in the Grand Manan Basin from May through October 2002 among $(\mathrm{a}, \mathrm{c}, \mathrm{e}) \mathrm{small}$, intermediate, and large size-classes of $C$. finmarchicus $\mathrm{C} 5 \mathrm{~s}$ and $(\mathrm{b}, \mathrm{d}, \mathrm{f})$ all sizes combined; numbers over bar in (b): no. of collections analysed. $(\mathrm{a}, \mathrm{b})$ Concentration $\left(\mathrm{m}^{-3}\right),(\mathrm{c}, \mathrm{d})$ individual gross energy content $(\mathrm{J})$ and $(\mathrm{e}, \mathrm{f})$ gross energy density $\left(\mathrm{kJ} \mathrm{m}^{-3}\right)$

(197.4 $\mathrm{m}^{-3}$; Fig. 9a) and gross energy density (0.76 kJ $\mathrm{m}^{-3}$; Fig. 9e) were observed in August, though no different from September $\left(0.63 \mathrm{~kJ} \mathrm{~m}^{-3}\right)$. The large C5 average concentration and gross energy density in August and September were higher than any other month ( $\mathrm{p}<0.0001, \mathrm{HSD})$. When all size-classes are combined, the highest gross energy density $\left(3 \mathrm{~kJ} \mathrm{~m}^{-3}\right)$ is observed in September (Fig. 9f, p = 0.0002, HSD).

As seen above for gross energy density, the intermediate $\mathrm{C} 5 \mathrm{~s}$ provided the highest WE and TOT energy density (Fig. 10). Small C5s reach their highest individual WE (Fig. 10c) and TOT (Fig. 10g) in October when their average WE and TOT energy density estimates (Fig. 10e,i) were the highest observed at 0.680 and $0.878 \mathrm{~kJ} \mathrm{~m}^{-3}$ respectively. Average WE energy density for small C5s (Fig. 10e) was higher in October than for all other the months, except for September, and was higher in September than in May and July ( $p=0.0002$, HSD). Small
C5 average TOT energy density (Fig. 10i) was higher in September and October than in all other months ( $p<0.0001$, HSD). Intermediate C5 individual WE and TOT (Fig. 10c,g) were highest in October and WE energy density and TOT energy density (Fig. 10e,i) were highest in October $\left(1.9 \mathrm{~kJ} \mathrm{~m}^{-3}\right)$ and September $\left(2.5 \mathrm{~kJ} \mathrm{~m}^{-3}\right)$, respectively. Both $\mathrm{WE}$ and TOT energy density of intermediate $\mathrm{C} 5 \mathrm{~s}$ were no different in August, September and October and each of these averages was higher than in May and July ( $p<0.0001$, HSD). Large C5 individual WE and TOT were highest in October (Fig. 10c,g) and WE and TOT energy density (Fig. 10e,i) reached their average maxima (1.35 and $1.71 \mathrm{~kJ}$ $\mathrm{m}^{-3}$, respectively) in August. The average for each estimator in August was no different from September and October, and the normalized averages for August and September were higher than in May $(p<0.0001$ HSD). When all size-classes are combined, the highest WE energy density (3.0 $\mathrm{kJ} \mathrm{m}^{-3}$; Fig. 10f) and TOT energy density (3.8 $\mathrm{kJ} \mathrm{m}^{-3}$; Fig. 10j) were observed in October, though they were no different from August and September. Averages for each energy density estimator in August, September and October were higher than in May and July ( $p<0.0001$, HSD).

Estimates of WE and total lipid energy density were often higher (up to 3-fold) than the calorimetric gross energy density estimates (Fig. 11). However, the ratio between collection-specific gross energy content (J) and the associated estimates of individual WE were close to a 1:1 relation among size-classes and stationcollections (Fig. 11a,c). The total lipid estimates are consistently higher than EC (Fig. 11b,d) and may be explained by an overestimation of polar lipid on the Iatroscan (Michaud 2005). Errors around both energy estimates are large and related to the high variance in individual weight-specific energy content as determined (data not presented) by a comparison of dry weight-specific lipid content and dry weight-specific gross energy content where the average (regardless of size or month) C5 dry weight-specific gross energy content was $32.1 \mathrm{~kJ} \mathrm{~g}^{-1}(\mathrm{SD}=13.5)$ and dry weightspecific WE content was $745.3 \mu \mathrm{g} \mathrm{mg}^{-1}(\mathrm{SD}=102.14)$. If we justifiably assume that WE has an energy value 

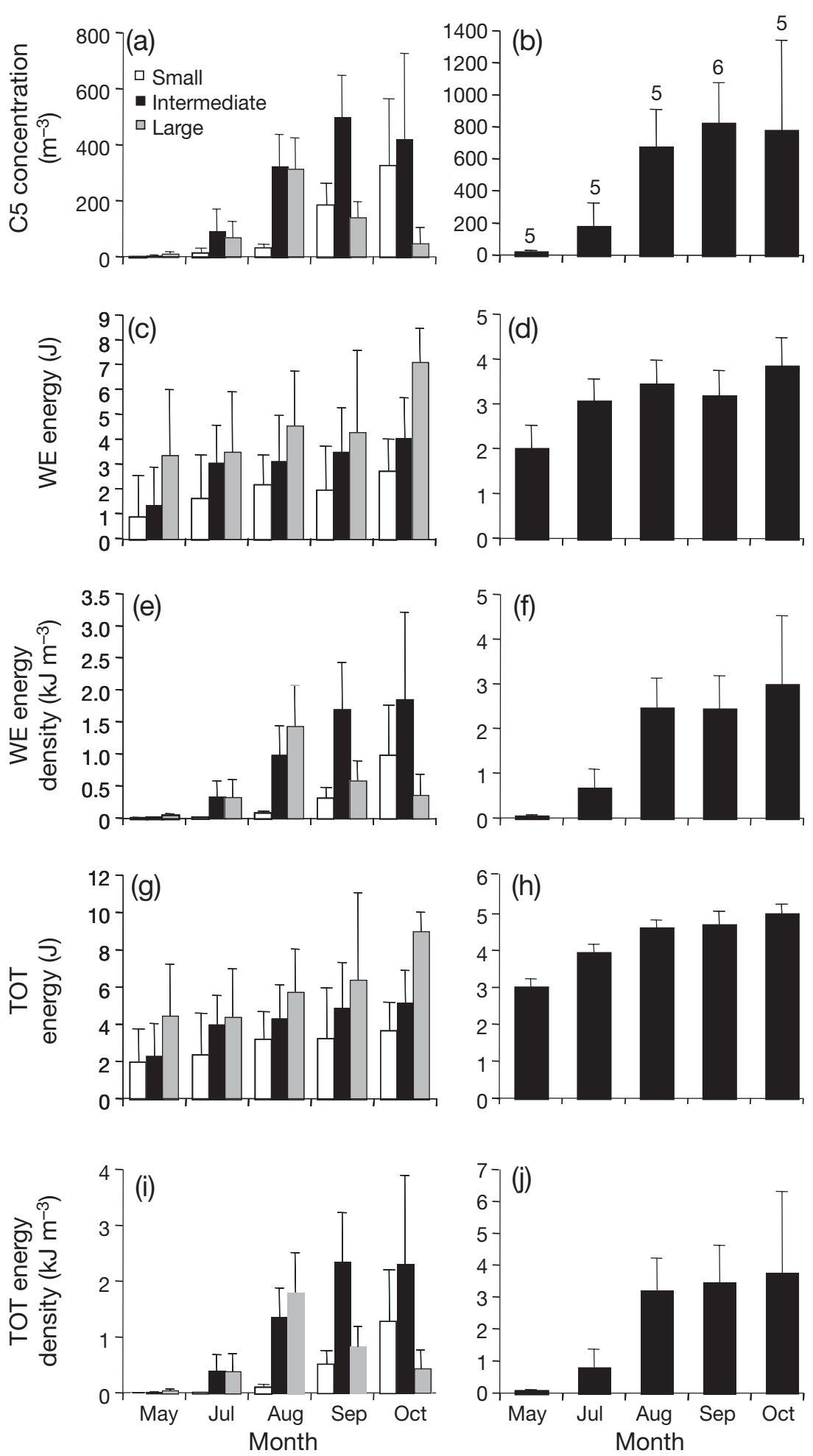

Fig. 10. Calanus finmarchicus. Histograms illustrating changes in monthly average $(+2 \mathrm{SE})$ estimates in the Grand Manan Basin from May through October 2002 among $(\mathrm{a}, \mathrm{c}, \mathrm{e})$ small, intermediate, and large C. finmarchicus C5 size-classes and $(b, d, f)$ combined classes; numbers over bar in $(b)$ : no. of collections analysed. $(\mathrm{a}, \mathrm{b})$ Concentration $\left(\mathrm{m}^{-3}\right),(\mathrm{c}, \mathrm{d})$ individual wax ester (WE) energy content $(\mathrm{J}),(\mathrm{e}, \mathrm{f})$ WE energy density $\left(\mathrm{kJ} \mathrm{m}^{-3}\right),(\mathrm{g}, \mathrm{h})$ individual total lipid (TOT) energy content $(\mathrm{J})$, and $(\mathrm{i}, \mathrm{j})$ TOT energy density $\left(\mathrm{kJ} \mathrm{m}^{-3}\right)$ of $39.5 \mathrm{~kJ} \mathrm{~g}^{-1}$ lipid (as above), we obtain an average energy equivalent of $29.4 \mathrm{~kJ} \mathrm{~g}^{-1}(\mathrm{SD}=4.03)$ for $\mathrm{WE}$ alone and $39.5 \mathrm{~kJ} \mathrm{~g}^{-1}(\mathrm{SD}=0.33)$ for average TOT dry-weight specific energy content. Thus, within the error limits, the overall estimates are equivalent on a dry weight-specific basis.

\section{DISCUSSION}

Zooplankton in the Grand Manan Basin during the May-to-October season reveal 2 characteristic periods: late spring and early summer (May through July), when zooplankton biomass and C5 concentration and energy density are relatively low, and late summer and early autumn (August through October), when each measure is significantly higher. Each of depth-integrated zooplankton biomass, C5 concentration, lipid content and lipid and gross energy density reach their maxima in September and October. Hence, the food energy available to right whales reaches its maximum during the same period when the whales are most concentrated in the Basin. We can quantify this association using NARW survey data for 2002 (NAWRC 2005). The first recorded NARW sighting in the Bay of Fundy in 2002 occurred on 3 July and the last on 10 October. These dates provide timing estimates of ingress and egress to and from the feeding habitat in 2002. Further, the monthly evolution of right whale sightings per unit effort (SPUE; right whales $\mathrm{km}^{-1}$ survey track) for the area encompassing the zooplankton sampling region in our study, and aggregated on a monthly basis over 2002, directly parallels the monthly evolution in C5 concentration and energy density (Fig. 12). When standardized (0 to 1 ), each measure of the prey field is strongly correlated $(\mathrm{n}=$ 5 , df = 3) with the SPUE estimates $\left(\mathrm{r}^{2}=0.96, \mathrm{p}=0.0039\right.$ for C5 concentration and $\mathrm{r}^{2}=0.88, \mathrm{p}=0.0178$ for gross energy density). Thus it ap- 

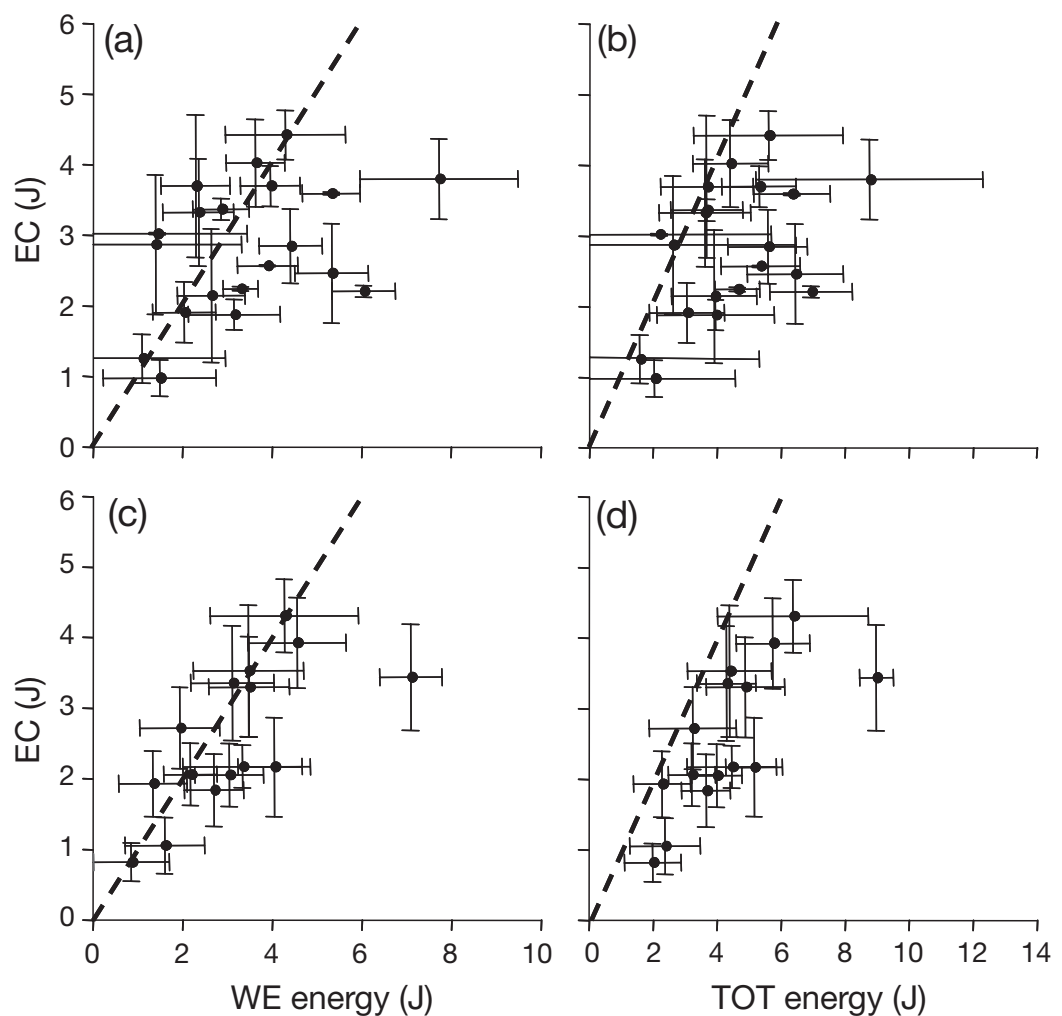

Fig. 11. Calanus finmarchicus. Relations between individual C5 total energycontent $\left(\mathrm{EC}_{i} \mathrm{~J}\right)$ and wax ester (WE) and total lipid energy-content (TOT, J) based on $(\mathrm{a}, \mathrm{b}) \mathrm{C} 5$ size-class and collection basis and (c,d) C5 size-class and monthly average. Dashed line illustrates a 1:1 relation

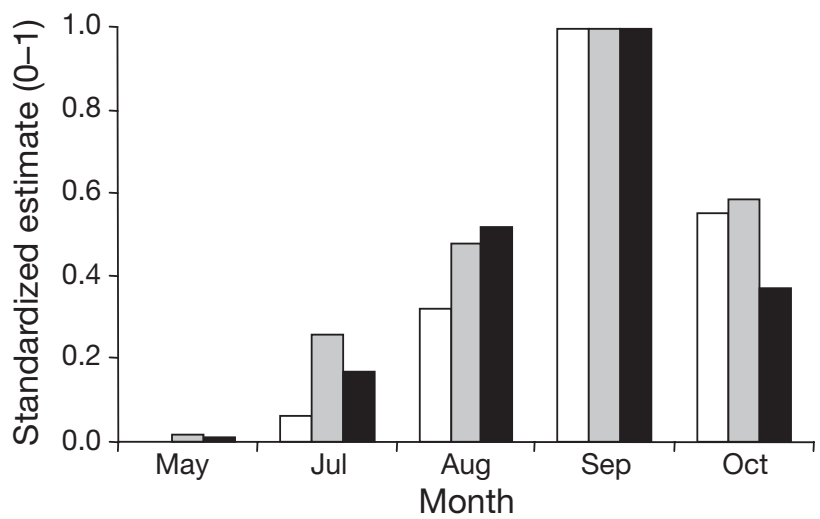

Fig. 12. Eubalaena glacialis and Calanus finmarchicus. Histograms illustrating parallel changes among the monthly standardized (0-1) estimates of right whale sightings per unit effort (whales $\mathrm{km}^{-1}$ survey track, open), depth-integrated concentration of $\mathrm{C} 5 \mathrm{~s}\left(\mathrm{~m}^{-3}\right.$, shaded) and total energy density $\left(\mathrm{kJ} \mathrm{m}^{-3}\right.$, solid) in the Grand Manan Basin region during the period May through October 2002

pears that the right whales occupy the Grand Manan feeding habitat in direct proportion to the abundance and quality (i.e. energy density) of food available in the habitat.

\section{Monthly variation in zooplankton biomass, composition and abundance}

Calanus finmarchicus clearly dominates the mesozooplankton community in the Grand Manan Basin throughout the summer and autumn in both abundance and biomass. The variation in $\mathrm{C} 5$ abundance is primarily responsible for the variation in total zooplankton biomass, especially given the low abundance of larger zooplankton (at least as sampled using $333 \mu \mathrm{m}$-mesh nets). In the deep basins of the Scotian Shelf, C. finmarchicus $\mathrm{C} 5$ s reach maximum concentrations at depths below $200 \mathrm{~m}$, where individuals appear to continuously accumulate during summer (Sameoto \& Herman 1990). Data from our study and in Baumgartner \& Mate (2003) provide evidence that the Basin region has substantial late-summer and early-autumn concentrations of C5s $\left(\sim 1000 \mathrm{~m}^{-3}\right)$ comparable to those in Emerald Basin, Scotian Shelf (Sameoto \& Herman 1990) and on Georges Bank (Meise \& O'Reilly 1996) and perhaps lower than in the Gulf of Maine (Meise \& O'Reilly 1996). However, such spatial and temporal comparisons warrant caution as various studies indicate a south to north gradient in the production timing of $C$. finmarchicus on the northwest Atlantic shelf. Decadal patterns of abundance indicate that maximum concentrations are generally encountered between March and April on Georges Bank and between July and August farther north in the Gulf of Maine (Meise \& O'Reilly 1996). In the Grand Manan Basin, slightly north of the Gulf of Maine, we observed the highest abundance in August through October. McLaren et al. (2001) show water column-integrated maximum concentrations of copepodites on the Scotian Shelf are observed between May and early July, somewhat earlier than in regions to the south.

\section{Monthly variation in the abundance and size distribution of $\mathrm{C} 5 \mathrm{~s}$}

The size distribution of the C5s across months in the Grand Manan Basin indicates at least 2 generations per year that are distinguishable in May. The C5s of the first observed generation $\left(\mathrm{G}_{1}\right)$ are relatively rare, larger and presumably developed earlier (in colder water) than the second $\left(G_{2}\right)$ and more abundant generation (see below). The $\mathrm{G}_{1}$ disappears from the water 
column in subsequent months as it is replaced by the $\mathrm{G}_{2}$ in August. This $\mathrm{G}_{2}$ persists through September and is supplemented or replaced by another generation, and constitutes the majority of an energy-rich prey field during the maximum presence of right whales.

On the Scotian Shelf, and depending on water temperature and location, Calanus finmarchicus of the emerging generation $\left(\mathrm{G}_{0}\right)$ spawn between February and March and the copepodites take 2 to 3 mo to reach C5 $\left(\mathrm{G}_{1}\right)$ when they either enter diapause (McLaren et al. 1989) or moult to adult to produce a $G_{2}$ (Sameoto \& Herman 1990), some of which may produce a $G_{3}$ (McLaren et al. 1989). These generations are differentiated by size (McLaren et al. 1989, 2001) and those developing in colder water yield larger individuals than those developing in warmer water (Comita et al. 1966, McLaren et al. 1989). Thus, the pattern we observed in the size distribution of $\mathrm{C} 5 \mathrm{~s}$ in the Basin is consistent with the presence of a $G_{1}$ and a $G_{2}$ at the end of May and is consistent with McLaren et al. (2001). The shift in size toward significantly smaller C5s between August and September and again between September and October suggests a new generation (a locally produced $\mathrm{G}_{3}$ or a $\mathrm{G}_{n}$ from elsewhere) as sometimes observed on the Scotian Shelf (McLaren et al. 1989, Sameoto \& Herman 1990). The question of whether these $\mathrm{C} 5 \mathrm{~s}$ are locally produced or are advected into the Bay of Fundy is not easily answered, though we address it below.

Sea surface temperature (SST) estimates derived from NOAA-16 satellites images (Rutgers, The State University of New Jersey, Institute of Marine and Coastal Sciences, New Brunswick, NJ) indicate that SST in the Grand Manan Basin area was 4 to $5^{\circ} \mathrm{C}$ between January and April 2002. Based on the wellmixed water column observed in the Basin in October and the weak stratification in May, we can reasonably assume that the SST approximates water column temperature over the October through May period. According to the Bělehrádek (1935) temperature function and the coefficients estimated for Calanus finmarchicus by Campbell et al. (2001), it takes approximately $56 \mathrm{~d}$ at $4{ }^{\circ} \mathrm{C}$ and at food saturation for a hatched nauplius to reach $\mathrm{C} 5$ and a further $20 \mathrm{~d}$ to reach maturity. Assuming that reproduction occurs in the Basin, and the $2 \mathrm{C} 5$ generations in May represent $G_{1}$ and $G_{2}$, then $G_{1}$ would have originated in early January and $\mathrm{G}_{2}$ in midMarch and each under similar temperature conditions. Accordingly, if the food conditions were similar, there should be no difference in size of the presumed $G_{1}$ and $\mathrm{G}_{2}$ generations in May. However, the mean difference of $\sim 0.3 \mathrm{~mm}$ is relatively large and consistent with intergenerational size differences reported by McLaren et al. $(1989,2001)$ that are related to temperature differences. Thus, the size differences in the 2 presumed generations in May might be explained by the transport of either one, or possibly both, into the Basin from elsewhere (e.g. the Scotian Shelf). Similarly, and again using the parameters of the Bělehrádek (1935) temperature function and assuming food saturation from Campbell et al. (2001), it would take $32 \mathrm{~d}$ at $8^{\circ} \mathrm{C}$ for a nauplius that hatched at the end of June to reach stage $\mathrm{C} 5$; hence, a third generation $\left(\mathrm{G}_{3}\right)$ of smaller individuals could be present in July. As the smaller C5s were observed mostly in August and September, the development time may be longer than that estimated using the Bělehrádek temperature function and/or may reflect sub-optimal food conditions. However, the absence of smaller C5s in July may alternatively indicate not a third generation but a second smaller generation of animals transported into the Grand Manan Basin rather than locally produced. Furthermore, the development of $C$. finmarchicus in the upper water column in July is less likely in the Grand Manan Basin because surface temperature was $>12^{\circ} \mathrm{C}$, above which nauplii and early copepodites experience high mortality (Runge \& McLaren unpubl. data, as cited by Zakardjian et al. 2003). Other authors have postulated that zooplankton are advected into the Bay of Fundy from the Scotian Shelf (Corey \& Milne 1987, Herman et al. 1991), the Gulf of Maine (Meise \& O'Reilly 1996), the Gulf of St. Lawrence via the Nova Scotia coastal current (Herman et al. 1991) and possibly the Labrador Sea via the Scotian shelf-break current (Sameoto \& Herman 1990, Head et al. 1999, McLaren et al. 2001).

\section{Monthly variation in C5 gross energy and lipid content}

As the summer progresses in the Grand Manan Basin, it is clear that C5s accumulate body mass in the form of lipids, mostly WE, resulting in elevated individual EC. The individual WE content, as a proportion of total lipid, increases markedly during summer to reach a maximum of $75 \%$ in October, similar to arctic copepods in which WE may represent $80 \%$ or more of total lipid (e.g. Falk-Petersen et al. 1987, Kattner \& Krause 1987, Kattner \& Hagen 1995). Lipid reserves are generally higher in species living in high latitudes, presumably an adaptation to a longer period of food shortage (Benson \& Lee 1975, Båmstedt 1986, Mauchline 1998). Seasonal variation in food supply also leads to greater variability in the lipid content at higher latitudes (Båmstedt 1986, Kattner 1989).

The individual C5 lipid content estimates we report are commensurate with estimates for Georges Bank and the Gulf of Maine (Miller et al. 1998), where individual C5 lipid content between February and July is among the highest reported for the species in the 
North Atlantic. The range in WE content we determined in May and July in the Basin is comparable to that for Georges Bank over the same period (Miller et al. 1998), although the median TOT estimates in May were lower than the mid-range TOT estimates for the same month on Georges Bank. This temporal difference in lipid content between regions is consistent with a south to north gradient in the production of Calanus finmarchicus (see above).

The increasing trend with latitude in lipid accumulation that is generally observed among copepods (Mauchline 1998) may not apply within a species, especially at distributional limits. For example, average summer lipid content in Calanus finmarchicus C5s at its northern limits was estimated at $72 \mu \mathrm{g}$ in Fram Strait (Kattner 1989) and at $50 \mu \mathrm{g}$ in the Svalbard area (Scott et al. 2000), half or less than that estimated for Georges Bank (Miller et al. 1998) and the Grand Manan Basin (present study). Scott et al. (2000) argued that delayed development and a prolonged spawning season, both related to low temperature, lead to energy allocated to growth in preference to lipid accumulation. Hence, the relation between latitude and intra-specific variation in energy content may be dome-shaped rather than linear, and energy storage may be maximal when the environmental conditions (e.g. food, temperature) are optimum for the species. However, Kattner (1989) argues that a disproportionate increase in the amount of certain long-chain fatty acids (20:1 and 22:1) composing the WE of C. finmarchicus in polar latitudes leads to higher energy content per unit mass of lipid when compare to that of temperate C. finmarchicus.

\section{Variation in C5 energy available to right whales}

In 2002, the water column average food energy density available to the right whale (and other consumers) increased by 2 orders of magnitude from May through September simply due to the monthly increase in concentration, biomass, lipid and gross energy content. In September 2002, when right whales are most abundant in the habitat, the water column average of gross energy from $\mathrm{C} 5 \mathrm{~s}$ prey field amounts to $3 \mathrm{~kJ} \mathrm{~m}^{-3}$, of which $84 \%$ is attributable to WE. We suggest that $3 \mathrm{~kJ}$ $\mathrm{m}^{-3}$ provides a reasonable minimum estimate of the energy density required to define suitable right whale feeding habitat, though such an estimate is subject to considerable spatial and temporal variation.

The analyses we have presented above illustrate that it is the generational production (either local or advected from elsewhere) of the prey and their resultant increase in concentration, coupled with the temporal increase in their energy content that influences the magnitude of the prey-field energy available. The abundance of Calanus finmarchicus emerging from winter diapause, the success of reproduction (Plourde \& Runge 1993), as well as the synchrony of development of the $\mathrm{G}_{1}$ and possibly ensuing generations of $\mathrm{C} 5 \mathrm{~s}$ with primary production can show inter-annual variation. The nature of that variation will determine the overall production of C. finmarchicus (e.g. McLaren et al. 1989) and the abundance of the $G_{1}, G_{2}$ (Sameoto \& Herman 1990, McLaren et al. 2001), and possibly $G_{3}$, and thus, the concentration of lipid-rich and diapausing $\mathrm{C} 5 \mathrm{~s}$ at the end of the summer when the right whales typically aggregate in the feeding habitat. The abundance of phytoplankton will influence the accumulation of C5 reserve lipid and, according to some authors, the amount of lipid accumulated by the C5s of $\mathrm{G}_{1}$ during spring may determine the number and the strength of the subsequent generations (e.g. McLaren et al. 2001, Irigoien et al. 2004). The C5 abundance variation in the Basin region is also a function of physical dynamics associated with the advection of $\mathrm{C} 5 \mathrm{~s}$ into or out of the Basin. The circulation over the Scotian Shelf is subject to strong seasonal and inter-annual variations that may enhance or limit the advection of C5s into the Grand Manan Basin (Hannah et al. 2000, Brickman et al. 2001).

Inter-annual variations in the above physical and biological processes will influence the C5 standing stock in the Basin in terms of abundance and quality and, thus, the feeding success of right whales during the summer and autumn period. Such variation will likely influence the timing of arrival and departure of the whales to and from the feeding habitat and the observed differences in residence time in the Basin (e.g. Kraus et al. 1982, Winn et al. 1986, Murison \& Gaskin 1989, Gaskin 1991). For example, if the local production or import of C5s into the Bay of Fundy is reduced in late autumn, the predation pressure of right whales and other predators (e.g. Atlantic herring, Atlantic salmon, sei whales) may be sufficient to reduce the $\mathrm{C} 5$ over-wintering population below a minimum threshold (Kenney et al. 1986, Baumgartner \& Mate 2003) such that the right whales leave the Basin region early. We postulate that a similar dynamic, early in the year, would result in either a late arrival of right whales to the habitat, or limited numbers of whales in the habitat over a contracted period, or the abandonment of the habitat such as has been observe in the Roseway Basin region of the Scotian Shelf (Clapham \& Cole 1999). In all cases, the proximate controlling variable that most likely explains inter-annual variability in whale occupancy of the feeding habitat appears to be energy density of the prey field - something that is clearly dependent on many other factors and processes summarized above. 
Part of the NARW species migrates to unknown feeding habitat(s) during summer (Kenney 2001) and the identification of areas suitable for successful feeding of right whales remains problematic. Our study shows that the abundance of the food, particularly C5s, and their energy content, is relevant in limiting the summer distribution of the right whale to habitats where conditions are optimum for growth and energy accumulation in its prey. Until better data are available, we suggest that right whales may not find better foraging when migrating to, or residing in, higher latitude habitats simply because the temperature and food conditions in such latitudes appear less favourable for threshold-level Calanus finmarchicus energy density. These copepod energy density levels are not easily achieved in high latitudes (e.g. Scott et al. 2000, and above) as a consequence of late reproduction, slower growth, delayed maturation, potentially lower individual energy content and limited generations (typically one in sub-arctic habitats; e.g. Kwasniewski et al. 2003). Scott et al. (2000) argue that C. finmarchicus is transported into Kongsfjorden (Svalbard), and diapausing C5s generally dominate the copepod assemblage at end of the summer and achieve concentrations of $200 \mathrm{~m}^{-3}$ and individual lipid content of $50 \mu \mathrm{g}$. Such concentrations and quantities of stored lipids amount to a lipid-based energy density of $0.23 \mathrm{~kJ} \mathrm{~m}^{-3}$; i.e. onetenth of that observed in the Grand Manan Basin during the same period.

The above suggested $3 \mathrm{~kJ} \mathrm{~m}^{-3}$ minimum estimate of energy density required to define suitable right whale feeding habitat is based solely on water column-integrated concentrations of C5s. The associated concentration estimates are similar to those estimated by Murison \& Gaskin (1989) and Woodley \& Gaskin (1996) in the 1980s in the same region. However, all of these estimates are lower than the minimum concentrations required to meet the energy demand of the NARW (Kenney et al. 1986, Baumgartner \& Mate 2003). It is reasonably clear that right whales forage at depth in the Basin and within narrow and concentrated layers of diapausing C5s (Baumgartner \& Mate 2003). Thus, accurate and more meaningful estimates of energy density will be depth-structured and depth-specific. Recent and parallel studies by Baumgartner \& Mate (2003) and Baumgartner et al. (2003b) in the Basin region report median deep-layer prey concentrations, derived from an optical plankton counter, at $6000 \mathrm{~m}^{-3}$. Furthermore, since more than one generation of $\mathrm{C} 5 \mathrm{~s}$ are present in the Basin, they may be in different stages of diapause (e.g. preparatory surface feeding stage vs. deep dwelling dormancy phase; see Hirche 1996 for a review). Thus, these C5s may be distributed in different depth layers in the water column and with different levels of lipid content. Baumgartner et al.
(2003) effectively report an active surface feeding population of C5s in July in the Grand Manan Basin. The energy density of the deep layers are orders of magnitude greater than water column-integrated estimates (Michaud 2005 and to be presented elsewhere), implying that variation in food concentration and food quality must be examined across various spatial (e.g. vertical distribution) and temporal scales (hours to days) and each matching the feeding dynamics of the right whale (we are currently documenting such estimates).

Finally, if questions related to variations in right whale condition and female reproductive capacity etc. are to be adequately addressed, the scale-matched measures of energy density available to the whales (above) are essential. Further, the existing energetic models developed for right whales (Kenney et al. 1986, Baumgartner \& Mate 2003) assume an individual C5 gross energy of $7 \mathrm{~J}$ when converting copepod and C5 concentrations to energy density. The conversion factor is based on gross energy estimated by Comita et al. (1966) in the NE Atlantic. Our study provides an average individual energy of 3.4 to $5 \mathrm{~J}$, based on gross energy and total lipid content respectively over many samples and several months. Thus, existing energetic models may be overestimating energy acquisition of right whales, at least in the Bay of Fundy habitat. In Cape Cod Bay the energy content of C5s based on carbon content estimated by DeLorenzo Costa et al. (2006) when using the conversion factor of Salonen et al. (1976) correspond to an energy value of 8.3 to $9.6 \mathrm{~J}$, thus, double the value we estimate using 2 different and more direct methods. Thus, we concur with DeLorenzo Costa et al. (2006) wherein they highlight the importance estimating temporal variation in the food energy content and in obtaining more precise estimates of the energy content. Perhaps more importantly, we suggest it is accurate estimates of whale food energy content and habitat energy density that are essential for modelling of right whale energy demand. We propose that when the depth-specific C5 concentrations such as those provided by Baumgartner \& Mate (2003) are well defined in time and space within the feeding domain in the Basin, and coupled with accurate measures of energy content, then the carrying capacity of the right whale feeding habitat will emerge.

Acknowledgements. We thank the officers and crews of the CAFV 'Quest' and RV 'Hart'; F. Desharnais, R. Stephenson, K. Smedbol, L. Harris and M. Brown for their support and W. Judge, K. Collins, D. Schillinger, T. Cheney, A. Serdynska and A. Vanderlaan for their assistance in the field and laboratory. Funding from FCAR to J.M. and from NSERC Ship-time and Discovery, DFO Science and Youth Internship Program, and the Species at Risk Program to C.T.T. supported the research. Three anonymous referees contributed to the improvement of this manuscript. 


\section{LITERATURE CITED}

Båmstedt U (1986) Chemical composition and energy content. In: Corner EDS, O'Hara SCM (eds) The biological chemistry of marine copepods. Clarendon, Oxford, p 1-58

Baumgartner MF, Mate BR (2003) Summertime foraging ecology of North Atlantic right whales. Mar Ecol Prog Ser 264: 123-135

Baumgartner MF, Cole TVN, Clapham PJ, Mate BR (2003a) North Atlantic right whale habitat in the lower Bay of Fundy and on the SW Scotian Shelf during 1999-2001. Mar Ecol Prog Ser 264:137-154

Baumgartner MF, Cole TVN, Campbell RG, Teegarden GJ, Durbin EG (2003b) Associations between North Atlantic right whales and their prey, Calanus finmarchicus, over diel and tidal time scales. Mar Ecol Prog Ser 264:155-166

Bělehrádek J (1935) Temperature and living matter. Protoplasma Monogr 8:1-277

Benson AA, Lee RF (1975) The role of wax in oceanic food chains. Sci Am 232:77-86

Bevington PR, Rombinson K (2003) Data reduction and error analysis for the physical sciences, 3rd edn. McGraw-Hill, Boston, MA

Bligh EG, Dyer WJ (1959) A rapid method of total lipid extraction and purification. Can J Biochem Physiol 37:911-917

Brickman D, Shackell NL, Frank KT (2001) Modelling the retention and survival of Browns Bank haddock larvae using an early life stage model. Fish Oceanogr 10:284-296

Brown RGB, Gaskin DE (1988) The pelagic ecology of the grey and red-necked phalaropes Phalaropus fulicarius and P. lobatus in the Bay of Fundy, eastern Canada. Ibis 130:234-250

Campbell RG, Wagner MM, Teegarden GJ, Boudreau CA, Durbin EG (2001) Growth and development rates of the copepod Calanus finmarchicus reared in the laboratory. Mar Ecol Prog Ser 221:161-183

Caswell H, Fujiwara M, Brault S (1999) Declining survival probability threatens the North Atlantic right whale. Proc Natl Acad Sci USA 96:3308-3313

Clapham PJ, Cole T (1999) Surveys for right whales and other mysticetes on the Scotian Shelf, summer 1999. North Atlantic Right Whale Consortium Annual Meeting published abstracts, Boston, MA

Comita GW, Marshall SM, Orr AP (1966) On the biology of Calanus finmarchicus XIII. Seasonal change in weight, calorific value and organic matter. J Mar Biol Assoc UK 46: $1-17$

Conover RJ, Wilson S, Harding GCH, Vass WP (1995) Climate, copepods and cod: some thoughts on the long-range prospects for a sustainable northern cod fishery. Clim Res 5:69-82

Corey S, Milne WR (1987) Recurrent groups of zooplankton in the Bay of Fundy and Southwest Nova Scotia regions, Canada. Can J Zool 65:2400-2405

Corten A (2000) A possible adaptation of herring feeding migrations to a change in timing of the Calanus finmarchicus season in the eastern North Sea. ICES J Mar Sci 57: $1261-1270$

DeLorenzo Costa A, Durbin EG, Mayo CA (2006) Variability in the nutritional value of the major copepods in Cape Cod Bay (Massachusetts, USA) with implications for right whales. Mar Ecol 27:109-123

Durbin EG, Gilman SL, Campbell RG, Durbin AG (1995) Abundance, biomass, vertical migration and estimated development rate of the copepod Calanus finmarchicus in the southern Gulf of Maine during late spring. Cont Shelf Res 15:571-591
Falk-Petersen S, Sargent J, Tande KS (1987) Lipid composition of zooplankton in relation to the Sub-Arctic food web. Polar Biol 8:115-120

Gaskin DE (1991) An update on the status of the right whale, Eubalaena glacialis, in Canada. Can Field Nat 105: 198-205

Hannah CG, Shore JA, Loder JW (2000) The drift-retention dichotomy on Browns Bank: a model study of interannual variability. Can J Fish Aquat Sci 57:2506-2518

Head EJH, Harris LR, Petrie B (1999) Distribution of Calanus spp. on and around the Nova Scotia Shelf in April: evidence for an offshore source of Calanus finmarchicus to the central and western regions. Can J Fish Aquat Sci 56: $2463-2476$

Herman AW, Sameoto DD, Chen S, Mitchell MR, Petrie B, Cochrane N (1991) Sources of zooplankton on the Nova Scotia and their aggregations within deep-shelf basins. Cont Shelf Res 11:211-238

Hirche H-J (1996) Diapause in the marine copepod, Calanus finmarchicus - a review. Ophelia 44:129-143

Irigoien X, Conway DVP, Harris RP (2004) Flexible diel vertical migration behaviour of zooplankton in the Irish Sea. Mar Ecol Prog Ser 267:85-97

Kane J (1984) The feeding habits of co-occurring cod and haddock larvae from Georges Bank. Mar Ecol Prog Ser 16: 9-20

Kattner G (1989) Lipid composition of Calanus finmarchicus from the North Sea and the Arctic. A comparative study. Comp Biochem Physiol 94B:185-188

Kattner G, Hagen W (1995) Polar herbivorous copepods different pathways in lipid biosynthesis. ICES J Mar Sci 52:329-335

Kattner G, Krause M (1987) Changes in lipids during the development of Calanus finmarchicus s.I. from Copepodid I to adult. Mar Biol 96:511-518

Kenney RD (2001) Anomalous 1992 spring and summer right whale (Eubalaena glacialis) distributions in the Gulf of Maine. J Cetacean Res Manage (Spec Issue) 2:209-233

Kenney RD, Hyman MAM, Owen RE, Scott GP, Winn HE (1986) Estimation of prey densities required by western North Atlantic right whales. Mar Mamm Sci 2:1-13

Kraus SD (1985) A review of the status of the right whale (Eubalaena glacialis) in the western North Atlantic with a summary of research and management needs. Final report to the Marine Mammal Commission. Rep Contract No. MM2910905-0

Kraus SD, Prescott JH, Turnbull PV, Reeves RR (1982) Preliminary notes on the occurrence of the North Atlantic right whale, Eubalaena glacialis, in the Bay of Fundy. Rep Int Whal Comm 32:407-411

Kraus SD, Hamilton PK, Kenney RD, Knowlton AR, Slay CK (2001) Reproductive parameters of the North Atlantic right whale. J Cetacean Res Manage (Spec Iss) 2:231-236

Kwasniewski S, Hop H, Falk-Petersen S, Pedersen G (2003) Distribution of Calanus species in Kongsfjorden, a glacial fjord in Svalbard. J Plankton Res 25:1-20

Lamprecht I (1999) Combustion calorimetry. In: Kemp RB (ed) Handbook of thermal analysis and calorimetry, Vol. 4. From macromolecules to man. Elsevier Science, Amsterdam, p 175-187

Mauchline J (1998) The biology of calanoid copepods. Academic Press, San Diego, CA

McEwen GF, Johnson MW, Folsom TR (1954) A statistical analysis of the performance of the Folsom plankton splitter based upon test observations. Arch Met Geophys Bioklim Ser A 7:502-527 
McLaren IA, Corkett CJ (1984) Life cycles and production of two copepods on the Scotian Shelf, eastern Canada. Nat Mus Can Syllogeus Ser 58:362-367

McLaren IA, Tremblay MJ, Corkett CJ, Roff JC (1989) Copepod production on the Scotian Shelf based on life-history analyses and laboratory rearings. Can J Fish Aquat Sci 46: 560-583

McLaren IA, Head E, Sameoto DD (2001) Life cycles and seasonal distributions of Calanus finmarchicus on the central Scotian Shelf. Can J Fish Aquat Sci 58:659-670

Meise CJ, O'Reilly JE (1996) Spatial and seasonal patterns in abundance and age-composition of Calanus finmarchicus in the Gulf of Maine and on Georges Bank: 1977-1987. Deep-Sea Res II 43:1473-1501

Michaud J (2005) The prey field of the North Atlantic right whale in the Bay of Fundy: spatial and temporal variation. Dalhousie University, Halifax, NS

Miller CB, Morgan CA, Prahl FG, Sparrow MA (1998) Storage lipids of the copepod Calanus finmarchicus from Georges Bank and the Gulf of Maine. Limnol Oceanogr 43:488-497

Murison LD, Gaskin DE (1989) The distribution of right whales and zooplankton in the Bay of Fundy, Canada. Can J Zool 67:1411-1420

NARWC (Non Atlantic Right Whale Consortium) (2005) Sightings database, 2 March 2005. New England Aquarium, Boston, MA

Ohman MD (1988) Sources of variability in measurements of copepod lipids and gut fluorescence in the California Current coastal zone. Mar Ecol Prog Ser 42:143-153

Planque B, Hays GC, Ibanez F, Gamble JC (1997) Large scale spatial variations in the seasonal abundance of Calanus finmarchicus. Deep-Sea Res 44:315-326

Plourde S, Runge JA (1993) Reproduction of the planktonic copepod Calanus finmarchicus in the lower St. Lawrence Estuary: relation to the cycle of phytoplankton production and evidence for a Calanus pump. Mar Ecol Prog Ser 102: 217-227

Posgay JA, Marak RR (1980) The MARMAP bongo zooplankton samplers. J Northw Atl Fish Sci 1:91-99

Salonen K, Sarvala J, Hakala I, Viljanen ML (1976) The rela-

Editorial responsibility: Sascha K. Hooker,

St. Andrews, UK tion of energy and organic carbon in aquatic invertebrates. Limnol Oceanogr 21:724-730

Sameoto DD, Herman AW (1990) Life cycle and distribution of Calanus finmarchicus in deep basins on the Nova Scotia shelf and seasonal changes in Calanus spp. Mar Ecol Prog Ser 66:225-237

Sameoto DD, Jarosynski LO, Fraser WB (1980) The BIONESS - new design in multiple net zooplankton samplers. J Fish Res Board Can 37:722-724

Schaeff CM, Kraus SD, Brown MW, White BN (1993) Assessment of the population structure of western North Atlantic right whales (Eubalaena glacialis) based on sighting and mtDNA data. Can J Zool 71:339-345

Scott CL, Kwasniewski S, Falk-Petersen S, Sargent JR (2000) Lipids and life strategies of Calanus finmarchicus, Calanus glacialis and Calanus hyperboreus in late autumn, Kongsfjorden, Svalbard. Polar Biol 23:510-516

Sokal RR, Rohlf FJ (1981) Biometry. 2nd edn. WH Freeman, San Francisco, CA

Stone GS, Kraus SD, Prescott JH, Hazard KW (1988) Significant aggregations of the endangered right whale, Eubalaena glacialis, on the continental shelf of Nova Scotia. Can Field-Nat 102:471-474

Winn H, Price C, Sorensen P (1986) The distributional biology of the right whale (Eubalaena glacialis) in the western North Atlantic. Rep Int Whal Comm: Spec Iss 10

Wishner KF, Schoenherr JR, Beardsley R, Chen C (1995) Abundance, distribution and population structure of the copepod Calanus finmarchicus in a springtime right whale feeding area in the southwestern Gulf of Maine. Cont Shelf Res 15:475-507

Woodley TH, Gaskin DE (1996) Environmental characteristics of North Atlantic right and fin whale habitat in the lower Bay of Fundy, Canada. Can J Zool 74:75-84

Zakardjian BA, Sheng J, Runge JA, McLaren I, Plourde S, Thompson KR, Gratton Y (2003) Effects of temperature and circulation on the population dynamics of Calanus finmarchicus in the Gulf of St. Lawrence and Scotian Shelf: study with a coupled, three-dimensional hydrodynamic, stage-based life history model. J Geophys Res 108, C11: 8016, doi:10.1029/2002JC001410

Submitted: June 14, 2006; Accepted: April 24, 2007

Proofs received from author(s): May 22, 2007 